\title{
Diamond and Other Exotic Mineral-Bearing Ophiolites on the Globe: A Key to Understand the Discovery of New Minerals and Formation of Ophiolitic Podiform Chromitite
}

\author{
Fei Liu ${ }^{1,2,3, *}$, Dongyang Lian ${ }^{4}$, Weiwei $W^{4}$ and Jingsui Yang ${ }^{1,3,4, *}$ \\ 1 Southern Marine Science and Engineering Guangdong Laboratory (Guangzhou), Guangzhou 511458, China \\ 2 Key Laboratory of Deep-Earth Dynamics, Institute of Geology, Chinese Academy of Geological Sciences, \\ Beijing 100037, China \\ 3 Shandong Academician Workstation of Diamond Mineralization Mechanism and Exploration, \\ Shandong No. 7 Exploration Institute of Geology and Mineral Resources, Linyi 276006, China \\ 4 School of Earth Sciences and Engineering, Nanjing University, Nanjing 210023, China; \\ ldy199008@163.com (D.L.); cugcags@163.com (W.W.) \\ * Correspondence: 1fhy112@126.com (F.L.); yangjsui@163.com (J.Y.)
}

check for updates

Citation: Liu, F.; Lian, D.; Wu, W.; Yang, J. Diamond and Other Exotic Mineral-Bearing Ophiolites on the Globe: A Key to Understand the Discovery of New Minerals and Formation of Ophiolitic Podiform Chromitite. Crystals 2021, 11, 1362. https://doi.org/10.3390/ cryst11111362

Academic Editor: Taijin Lu

Received: 30 September 2021

Accepted: 2 November 2021

Published: 8 November 2021

Publisher's Note: MDPI stays neutral with regard to jurisdictional claims in published maps and institutional affiliations.

Copyright: (c) 2021 by the authors. Licensee MDPI, Basel, Switzerland. This article is an open access article distributed under the terms and conditions of the Creative Commons Attribution (CC BY) license (https:/ / creativecommons.org/licenses/by/ $4.0 /)$.

\begin{abstract}
Ophiolite-hosted diamond from peridotites and podiform chromitites significantly differs from those of kimberlitic diamond and ultra-high pressure (UHP) metamorphic diamond in terms of occurrence, mineral inclusion, as well as carbon and nitrogen isotopic composition. In this review, we briefly summarize the global distribution of twenty-five diamond-bearing ophiolites in different suture zones and outline the bulk-rock compositions, mineral and particular Re-Os isotopic systematics of these ophiolitic chromitites and host peridotites. These data indicate that the subcontinental lithospheric mantle is likely involved in the formation of podiform chromitite. We also provide an overview of the UHP textures and unusual mineral assemblages, including diamonds, other UHP minerals (e.g., moissanite, coesite) and crustal minerals, which robustly offer evidence of crustal recycling in the deep mantle along the suprasubduction zone (SSZ) and then being transported to shallow mantle depths by asthenospheric mantle upwelling in mid-ocean-ridge and SSZ settings. A systematic comparison between four main genetic models provides insights into our understanding of the origin of ophiolite-hosted diamond and the formation of podiform chromitite. Diamond-bearing peridotites and chromitites in ophiolites are important objects to discover new minerals from the deep earth and provide clues on the chemical composition and the physical condition of the deep mantle.
\end{abstract}

Keywords: diamond; ophiolite; chromitite; peridotite; crustal recycling into deep mantle

\section{Introduction}

According to the differences in occurrence and genesis, natural diamonds are divided into various types, including diamonds occurring in kimberlite, lamproite, ophiolite, alkaline mafic rock, crust-derived ultrahigh-pressure (UHP) metamorphic rock, meteoroliterelated and alluvial rocks [1-5]. Ophiolites are fragments of ancient oceanic crust and upper mantle, which is created at ocean spreading ridges and then emplaced on land [6]. Ophiolite-hosted diamond discovered in ophiolitic peridotite and chromitite is considered to be a new type that has been named an ophiolite-type in recent years [4,7].

It has been hundreds of years since the first discovery of diamonds in ophiolites [8-10]. Diamonds were successively discovered in ophiolites from Quebec in Canada [8], Kamenusha in the Urals (Russia) and Koryak in the Far East [9,10]. However, these early stage studies merely reported the occurrence of diamonds in ophiolites but did not systematically relate these discoveries to plate tectonics. Since the 1980s, the diamond group in the Chinese Academy of Geological Sciences discovered diamonds in the Luobusa ophiolite (also named Qusong) in the Indus-Yarlung Zangbo suture zone (IYSZ) and Dongqiao ophiolite 
in the Bangong Nujiang suture zone (BNSZ) in Tibet, China [11-14]. Subsequently, Jingsui Yang and his group continued this research, and diamonds were also discovered in the ophiolites of Luobusa, Purang, Dongbo, Dangqiong and Dingqing in Tibet, Sartohay in Xinjiang, Hegenshan in Inner Mongolia, Myitkyina and Kalemyo in Myanmar, PozantiKarsanti in Turkey, Mirdita in Albania and Horoman in Japan [15-33]. As these diamonds were extracted by heavy mineral separation in the early stage, their natural origin was initially doubted $[7,34]$. However, it was not until the in situ diamonds were discovered in the Luobusa and Polar Ural chromitites as well as the Nidar mantle peridotites [24,35]. Particularly, ophiolite-hosted diamonds have inclusions of fluid and Mn-Co-Ni alloy and obviously show trace elements, e.g., $\mathrm{Ba}, \mathrm{Pb}$, Th and $\mathrm{Eu}$, and crust-derived carbon-nitrogen isotope compositions different from those of synthetic diamonds [5,36,37]. Following the independent discovery of diamonds in ophiolitic mantle peridotites and chromitites by Australian, Spanish and Indian geologists, the occurrence of the ophiolite-type diamond was widely accepted $[35,36,38,39]$.

Ophiolite-hosted diamond and other UHP minerals have been globally discovered in ophiolites from various orogenic belts, suggesting that diamonds are widespread in mantle rocks $[5,24,37,40]$. The discovery of ophiolite-hosted diamond opens a new field for research on the genesis of ophiolitic chromitite and host mantle peridotite and for the exploration of the dynamics of crust-mantle recycling [41-43]. However, the amounts of diamonds extracted from various ophiolitic peridotites and chromitites differ greatly. For most massifs, several diamond grains were recovered per ton, while over one thousand diamond grains per ton were discovered from the Luobusa mantle peridotites and chromitites. In contrast, less than ten diamond grains per ton were recovered from mantle peridotites in the Xialu (Xigaze), Zedang, Dongbo and Myitkyina massifs [40,44]. It is still unclear what contributes to the difference in such diamond concentrations. A discussion of the spatial distribution and formation mechanism of ophiolite-hosted diamond has become a new direction of current research of ophiolites and plate tectonics $[5,37,40]$. This paper summarizes the geological characteristics of diamond-bearing ophiolites and discusses the four genetic models for the diamond-bearing and associated unusual minerals-bearing ophiolites, providing a basis for discussing the formation of ophiolitic chromitite and the dynamic process of crust-mantle material recycling.

\section{Global Distribution of Diamond-Bearing Ophiolites}

Twenty-five diamond-bearing ophiolites have been discovered across the globe, and they are mainly distributed along the Tethyan Orogenic Belt, the Ural-Central Asian Orogenic Belt, the Hidaka metamorphic belt, the Klamath-Acatlán Orogenic Belt in North America and the Andean Orogenic Belt in South America (Figure 1a). The Tethyan Orogenic Belt is a giant and long-lived plate subduction-collision system on the earth that separates the Gondwana supercontinent to the south from the Laurasia supercontinent to the north [45]. It displays a structural difference of continent-continent collision alternating with ocean-continent subduction from east to west (Figure 1b). This belt extends from the Alpine continent-continent collisional orogenic belt in Europe via the complicated Mediterranean ocean-continent subduction belt, eastwards to the Zagros continent-continent collisional orogenic belt in West Asia and the Makrun ocean-continent subduction belt to the east, and to the Himalayan continent-continent collisional orogenic belt. Then it connects with the ocean-continent subduction zone formed by East Indian oceanic slab subducting below Southeast Asia [46]. The Tethyan Orogenic Belt represents an oceanic system remnant commonly composed of Prototethyan, Paleotethyan and Neotethyan oceans that developed during the Early Paleozoic, Late Paleozoic and Mesozoic, respectively [45]. The Paleotethyan ocean represented by late Paleozoic-Triassic ophiolites was bounded by the Cimmerides to the south that mainly consists of Anatolia, Persia, Afghanistan and Tibet, and Cathaysides to the north that includes South China, Indochina, Sibumasu and Qamdo blocks $[45,47,48]$. The Neotethyan ocean documents the Mesozoic rifting of Pangea and comprises multiple seaways formed by seafloor spreading and widening eastwards and 
deep mantle circulation processes, including several stages of slab subduction and mantle plume activities [49].
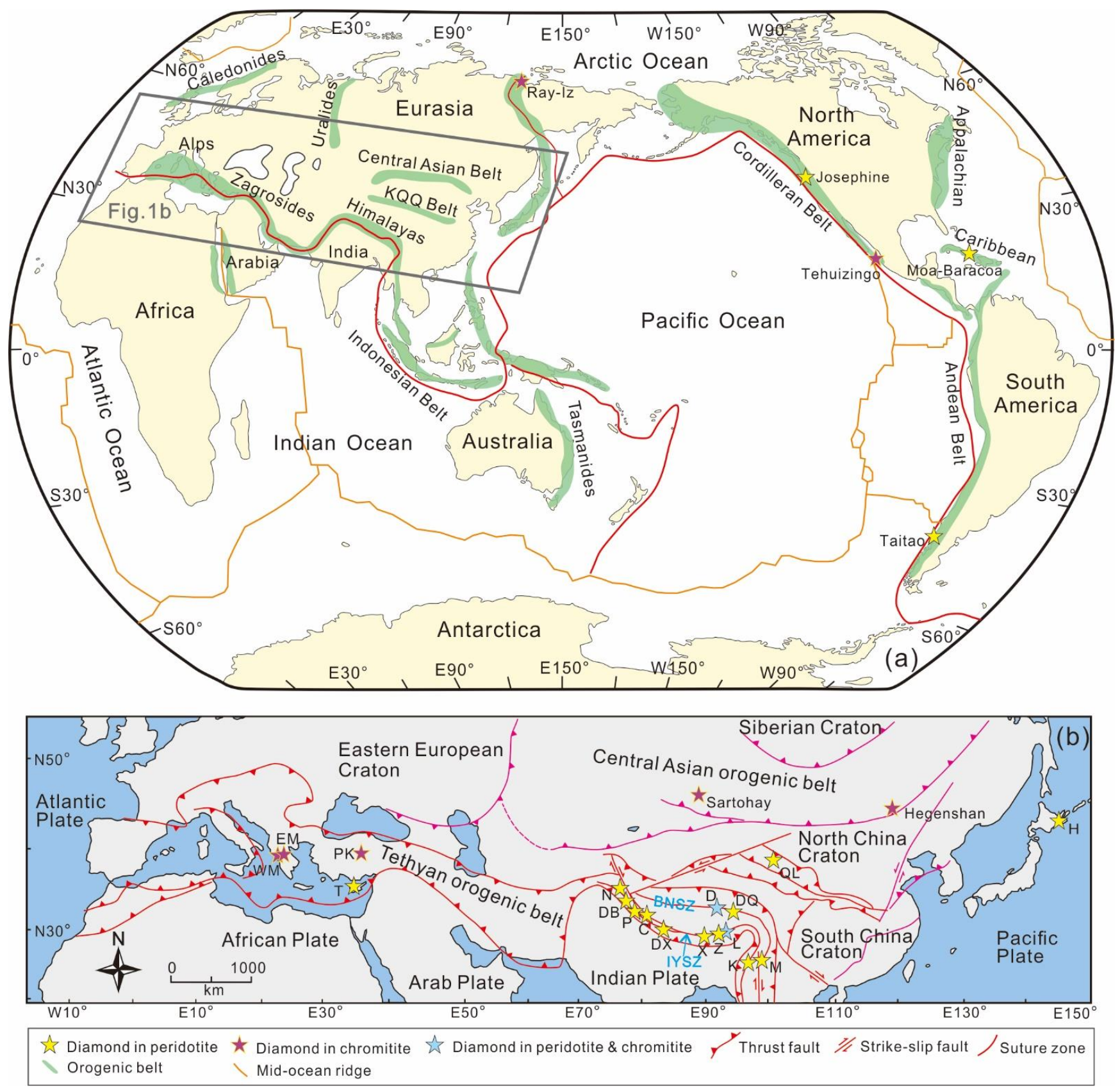

Figure 1. Distribution of twenty-five diamond-bearing ophiolites reported on the globe (a). Nineteen diamond-bearing ophiolites are distributed along the Neotethyan Orogenic Belt, Kunlun-Qilian-Qinling Paleotethyan Orogenic Belt (KQQ), Central Asian Orogenic Belt and Hidaka metamorphic belt (b). Ophiolites: C—Cuobuzha, D—Dongqiao, DB-Dongbo, DQ—Dingqing, DX—Dangqiong-Xiugugabu, EM-Eastern Mirdita (Albania), K-Kalamyo (Myanmar), L-Luobusa, M-Myitkyina (Myanmar), N-Nidar (Kashmir), P-Purang, PK—Pozanti Karsanti (Turkey), QL-Qilian, WM-Western Mirdita (Albania), X-Xialu, Z-Zedang. Ural-Central Asian Orogenic Belt: Sartohay, Hegenshan, Ray-Iz (Polar Urals). Hidaka Metamorphic Belt: H-Horoman (Japan). BNSZ—Bangong Nujiang suture zone, IYSZ—Indus Yarlung Zangbo suture zone. Internal structures are modified from [50-53].

The Neotethyan Orogenic Belt, which was discovered with fifteen diamond-bearing ophiolites, includes three subbelts of the BNSZ, IYSZ and the Eastern Mediterranean zone (Figure 1b). Diamond-bearing Dongqiao and Dingqing ophiolites occur in the BNSZ, 
Tibet [13,14,27]; the Myitkyina ophiolite is located in the Burmese Eastern ophiolitic belt that is regarded to be the southern continuation of the BNSZ [54]. The Luobusa, Zedang, Xialu, Dangqiong-Xiugugabu, Purang, Dongbo, Cuobuzha and Nidar ophiolites occur in the IYSZ [7,14,20,23,25,26,35,55-57]; the Kalamyo ophiolite crops out in the Indo-Burma Range that is regarded to be connected with the IYSZ [58]. The Pozanti Karsanti (Turkey), East Mirdita (Bulqiza, Albania) and West Mirdita (Skenderbeu, Albania) ophiolites occur in the Mediterranean ophiolite belt [28,30,32] (Figure 1b).

The 495-550 Ma diamond-bearing Yushigou ophiolite in the North Qilian Orogenic Belt represents the relics of the Prototethyan ocean [59]. Diamond-bearing ophiolites in the Ural-Central Asian Orogenic Belt consist of the Ray-Iz massif in the Polar Urals [24], the Sartohay ophiolite in Xinjiang and the Hegenshan ophiolite in Inner Mongolia [21,22] (Figure 1b). The diamond-bearing Horoman mantle peridotites [33], each $\sim 10 \mathrm{~km}$ long, $\sim 8 \mathrm{~km}$ wide and $\sim 3 \mathrm{~km}$ thick, are exposed along the southern edge of the NNW-SSE oriented, $\sim 120 \mathrm{~km}$ long and 10 20 km wide Hidaka metamorphic belt, which is the boundary between the North American Plate (Okhotsk block) and the Eurasian Plate [60]. The Klamath-Acatlán Orogenic Belt includes the Klamath massif in western United States and the Acatlán complex in southern Mexico [39]. Ophiolite-hosted diamonds in this belt were discovered in the Jurassic Josephine peridotite [61] and the Early Paleozoic Tehuitzingo chromitite [39], respectively. About ten diamond grains were discovered in the Moa-Baracoa ophiolitic peridotite massif in eastern Cuba, which is about $100 \mathrm{~km}$ long and $10-30 \mathrm{~km}$ wide, covering an area of $\sim 1500 \mathrm{~km}^{2}$ (Rui et al., in preparation). One diamond grain was obtained from the Taitao peridotite in Chile, the western part of the Andean Orogenic Belt (Wu et al., in preparation).

\section{Geochemical Characteristics of Diamond-Bearing Ophiolites}

The wall rocks of the ophiolite-hosted diamonds are podiform chromitite and mantle peridotite. Mantle peridotite is dominated by Cpx-bearing harzburgite (Figure 2). Diamondbearing lherzolite was merely reported in the Purang and Horoman massifs [33,56]. Ophiolites in the IYSZ, including the Purang, Dongbo, Cuobuzha, Dangqiong, Xialu, Zedang and Luobusa massifs, commonly have harzburgites with low contents of $\mathrm{Al}$ and $\mathrm{Ca}$ but high contents of $\mathrm{Mg}$ relative to the primitive mantle. The REE and Os contents of these harzburgites are notably lower than those of the primitive mantle. These geochemical features are comparable with those of depleted abyssal peridotites, which have experienced variable degrees of partial melting [62,63]. Some samples are relatively enriched in LREE, $\mathrm{Rb}$ and $\mathrm{Ba}$ and have a comparatively large range of $\mathrm{Cr}^{\#}\left(\mathrm{Cr}^{\#}=100 \times \mathrm{Cr} /(\mathrm{Cr}+\mathrm{Al}), 18-75\right)$ in chromite (Cr-spinel). The diamond-bearing peridotites commonly show higher contents of platinum group elements (PGE) than those of the primitive mantle. Such geochemical characteristics suggest that these depleted abyssal peridotites were widely metasomatized by sulfide-rich, incompatible element-rich and high-PGE fluids/melts [62-65].

In a rock-melt interaction process, Re-Os isotopes can reflect the impacts of infiltrating melts on the ophiolitic mantle [66,67]. Os is a highly compatible element during partial melting, while Re is a moderately incompatible element, which leads to comparatively low $\mathrm{Re} / \mathrm{Os}$ ratios and increases the ${ }^{187} \mathrm{Os} /{ }^{188} \mathrm{Os}$ ratio in residual mantle peridotites, although the rate of growth reduces over time [66-68]. Thus, the lower ${ }^{187} \mathrm{Os} /{ }^{188}$ Os ratios recorded in peridotites may indicate an earlier local melting event $[63,68]$. In addition, serpentinization, seafloor alteration and metasomatism of mantle peridotites by fluids/melts pose weak impacts on the whole rock's ${ }^{187} \mathrm{Os} /{ }^{188} \mathrm{Os}$ ratio, and thus, the Re depletion model ages can reflect the time of partial melting $[67,68]$. Compared to the average ${ }^{187}$ Os $/{ }^{188}$ Os ratio of a primitive upper mantle (0.1296) [69], seventy-eight ${ }^{187} \mathrm{Os} /{ }^{188} \mathrm{Os}$ ratios $(0.113-0.145$, with an average of 0.125) of the Purang, Dongbo and Cuobuzha harzburgites in the western segment of IYSZ overlap the ranges of the subcontinental lithospheric mantle (SCLM, 0.105-0.129) [70] and depleted oceanic lithospheric mantle (0.123-0.129) [70,71]. The Baigang and Dazhuqu mantle peridotites in central IYSZ display a relatively large range in ${ }^{187} \mathrm{Os} /{ }^{188} \mathrm{Os}(0.118-0.130$, with an average of 0.126$)$. Additionally, sixty-eight 
${ }^{187} \mathrm{Os} /{ }^{188} \mathrm{Os}$ ratios of Luobusa and Zedang mantle peridotites in the eastern segment show a comparatively large range $(0.121-0.137$, with an average of $0.126[63,72,73]$. They all show hybrid signatures of depleted oceanic lithosphere and SCLM (Figure 3).

\section{(a) Dingqing (DQ)}

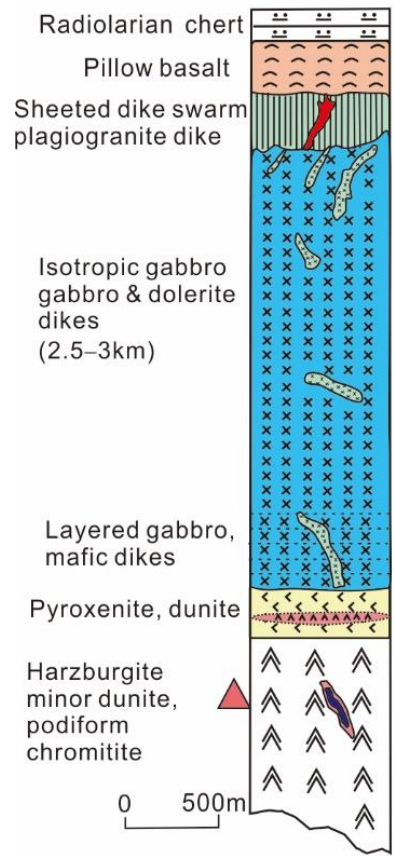

(e) Dangqiong-Xiugugabu (DX)
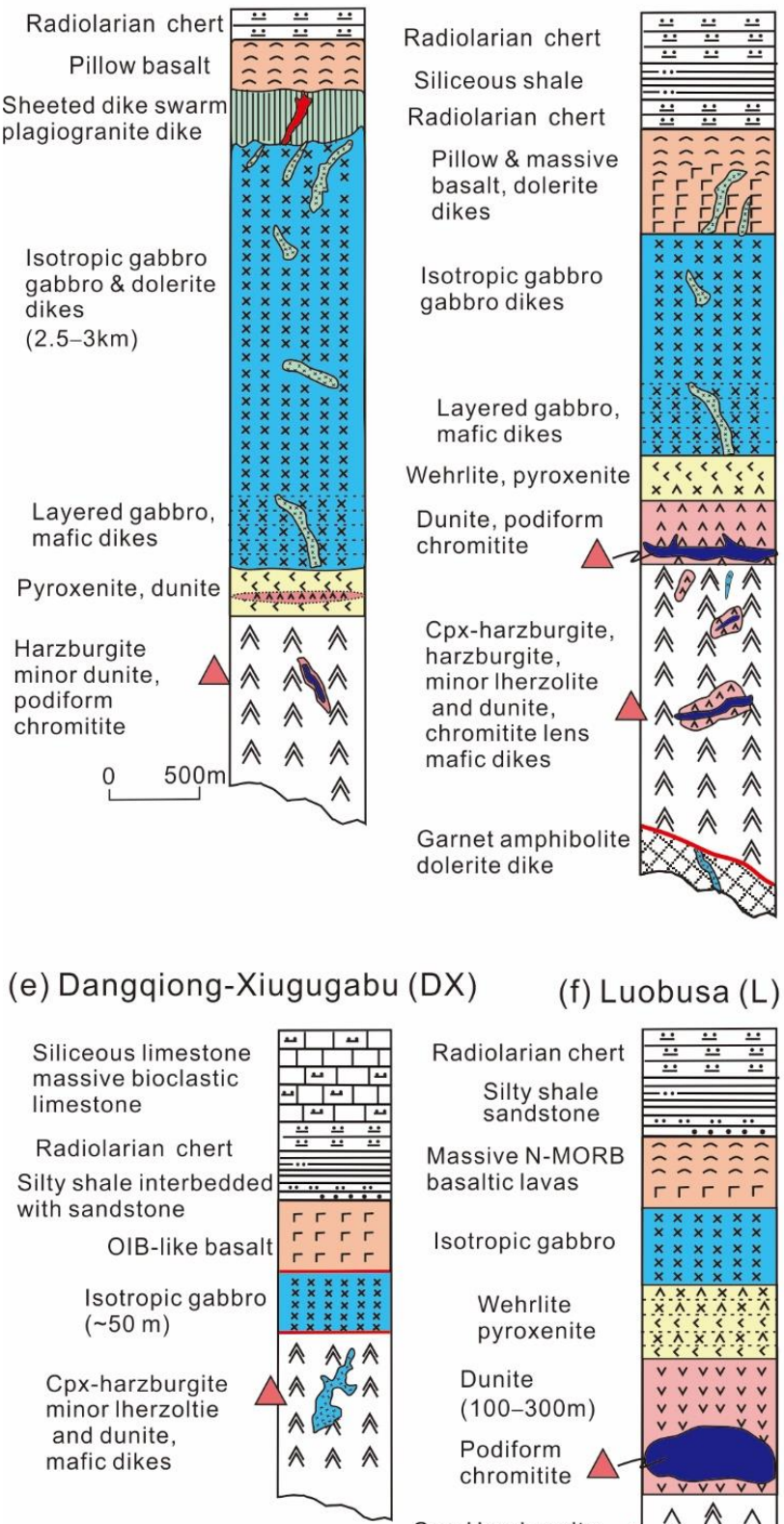

(b) Dongqiao (D)

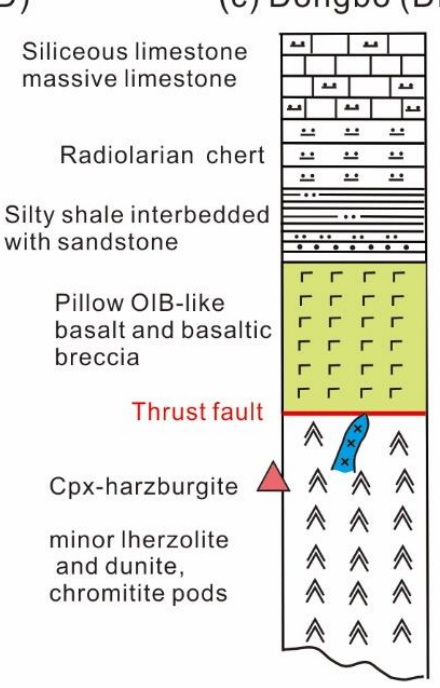

(g) Xialu (X)

\section{Radiolarian chert \\ Silty shale sandstone}

Pillow \& massive N-MORB-like basaltic lavas

Sheeted dikes, minor gabbro lenses, trondhjemite, quartz diorite dikes

Cumulated complex (layered gabbro, troctolite, dunite)

Wehrlite, pyroxenite Cpx-Harzburgite, harzburgite, dunite, mafic dikes

Lherzolite, Cpx-Harzburgite, mafic dikes

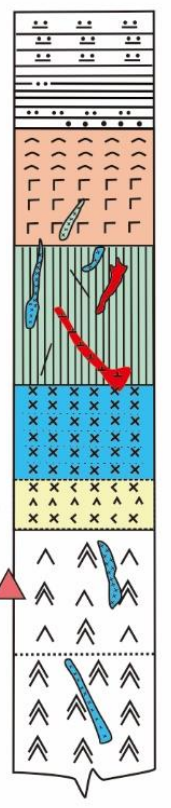

Massive and siliceous limestone (10-30 m)

Radiolarian cher (50-80 m)

Basalt (E-MORB-like) (20-30 m)

Radiolarian chert (30-60 m)

Thrust fault

Cpx-harzburgite with minor dunite minor Iherzolite

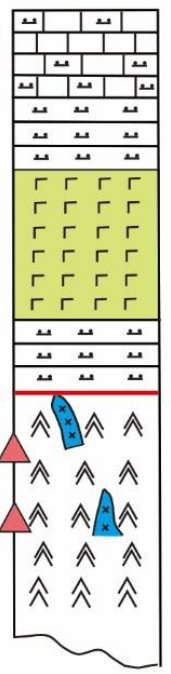

(h) East Mirdita (EM)

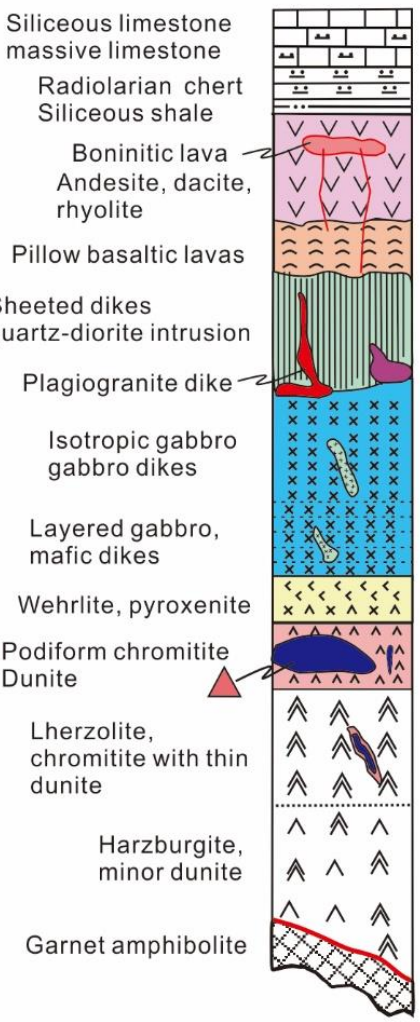

Figure 2. Compiled stratigraphic-lithological columnar sections of the main diamond-bearing ophiolites shown in Figure $1 \mathrm{~b}$ along the Neotethyan Orogenic Belt. Red triangles labeled as diamonds hosted in podiform chromitite, harzburgite and lherzolite. (a) Dingqing ophiolite from the eastern part of the BNSZ, Tibet [27,44]; (b) Dongqiao ophiolite from the central part of the BNSZ, Tibet [13,14,44]; (c) Dongbo, (d) Purang and (e) Xiugugabu ophiolites from the wetern part of the IYSZ [44]; (f) Luobusa ophiolite from the eastern part of the IYSZ [14,16,17]; (g) Xialu ophiolite from the central part of the IYSZ [26,44]; (h) East Mirdita (Bulqiza massif) from the eastern Mediterranean ophiolite belt [28]. 


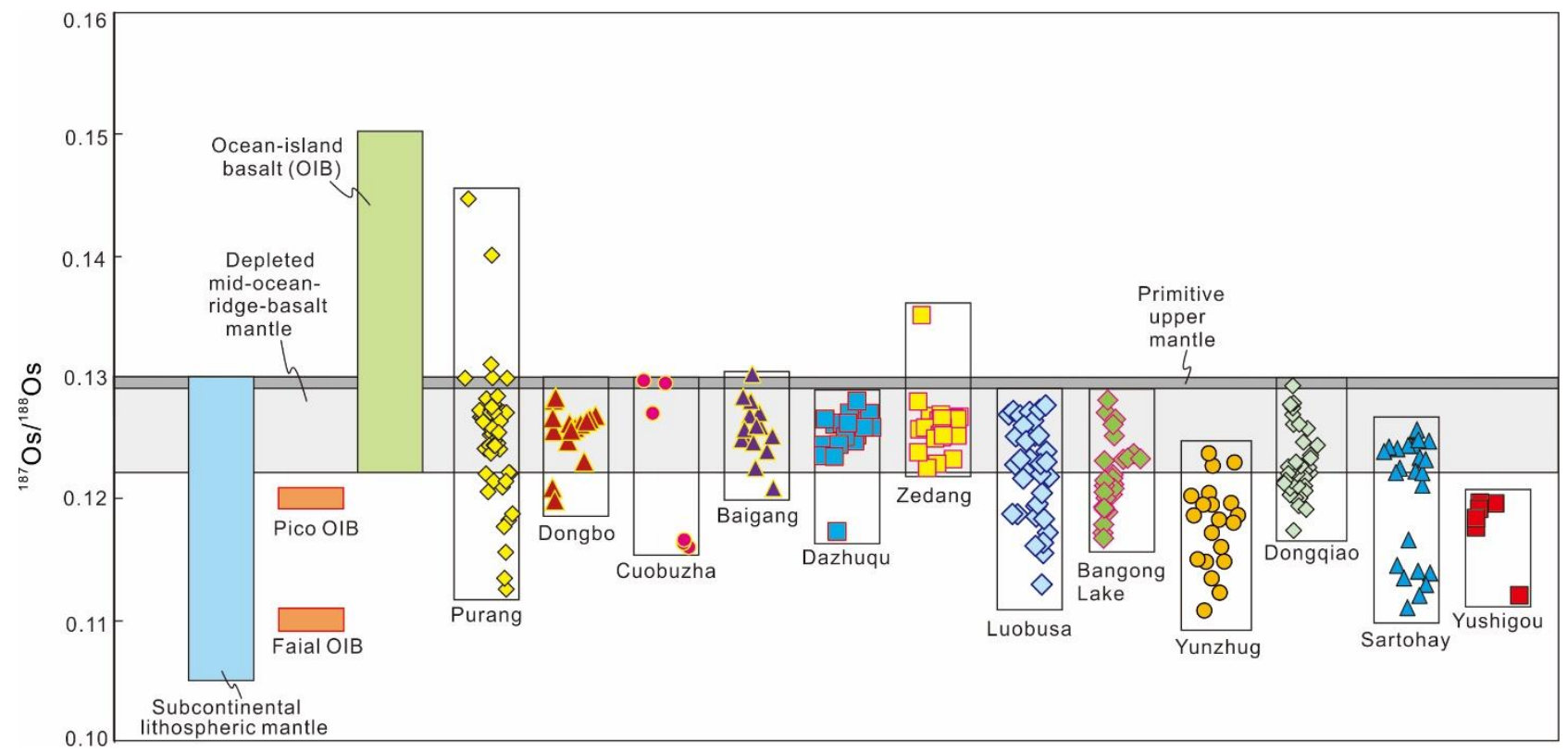

Figure 3. Osmium isotopic values of diamond-bearing chromitite and peridotite in different ophiolites. Osmium isotopic values of primitive upper mantle, depleted mid-ocean-ridge-basalt mantle, Ocean-island basalt (OIB), Pico and Faial OIB from the Azores after [71]. Osmium istotopic data references: Purang [63,74,75]; Dongbo [62]; Cuobuzha [65]; Baigang [63]; Dazhuqu [76]; Zedang [63,77]; Luobusa [72,78,79]; Bangong Lake [80]; Yunzhug [81]; Dongqiao [67,79,82]; Sartohay [79]; Yushigou [59].

Podiform chromitite is defined as lenticular aggregates of chromite formed in Alpinetype peridotites and oceanic crust-mantle transition zones [83], and it normally contains over 20 vol.\% chromite, and preserves abundant magma rheological and high-temperature deformation structures that are distinct from those of layered chromitite $[83,84]$. Podiform chromitite, by occurrences and $\mathrm{Cr}$ values of chromite, may be classified as follows: (1) According to the exposed locations of chromitite orebodies in a well-exposed ophiolitic sequence, ophiolite can be divided into subvarieties occurring below and within the MOHO transition zone $[83,85,86]$. The former is mostly enclosed in harzburgite with a thin dunite-envelope and usually occurs as large-sized deposits of economic value. The latter is generally distributed in thin-bedded dunite and usually forms small-sized, disseminated and banded chromitite deposits, which are commonly interlayered with cumulate dunite [86]. (2) According to the structural deformation features of podiform chromitite orebodies, chromitite deposits are mainly divided into discordant, subconcordant and concordant types compared with permeable structures of foliation and lineation developed in host mantle peridotites [87]. Discordant ore bodies are irregular and obviously cut through the foliation and lineation of peridotites, subconcordant orebodies usually have angles of $10^{\circ}-25^{\circ}$ with the foliation, and concordant ore bodies are commonly parallel to the foliation and lineation [87]. (3) According to the chromite aggregation forms, podiform chromitites are divided into massive, nodular, antinodular, densely/sparsely disseminated, banded and vein-like types $[85,88,89]$. (4) According to geochemical compositions of chromite in podiform chromitite, it can be divided into high- $\mathrm{Cr}\left(\mathrm{Cr}^{\#}\right.$ value $\left.>60\right)$ type and high-Al $\left(\mathrm{Cr}^{\#}\right.$ value $\left.<60\right)$ type [90]. High-Al chromitite is usually considered to be precipitated from basaltic melts, which might be formed at a mid-ocean ridge (MOR) or derived from backarc or forearc settings at a suprasubduction zone (SSZ). High-Cr type is generally related to boninitic melt metasomatism in subduction zones [91,92]. Recently, Li et al. (2019) further subdivided chromitite from the Dingqing ophiolite in the BNSZ, China, into high- $\mathrm{Cr}\left(\mathrm{Cr}^{\#}=78-86\right)$, medium-high- $\mathrm{Cr}\left(\mathrm{Cr}^{\#}=60-74\right)$, medium- $\mathrm{Cr}\left(\mathrm{Cr}^{\#}=30-51\right)$ and low-Cr $\left(\mathrm{Cr}^{\#}=9-14\right)$ types [89].

Ophiolite-hosted diamonds occur in both high-Cr chromitite, e.g., the Ray-Iz and Luobusa ophiolites [24,93], as well as in high-Al chromitite, e.g., the Sartohay and Hegen- 
shan ophiolites [21,22]. They even have been recovered from high-Al and high-Cr type chromitites in the same ophiolite massif such as Dongbo, Purang, Dingqing, Mirdita and Pozanti Karsanti $[29,32,89,94]$. Current statistics show that the amount of diamond grains in high-Cr type chromitite is much higher than those in high-Al type chromitite [40]. For example, the number of diamond grains from the Luobusa, Kangjinla and Ray-Iz massive high-Cr chromitites reaches 1000 per ton in total $[20,24,57]$, while in both high-Al type and high-Al-high-Cr type chromitites from, e.g., the Dongbo and Purang ophiolites, there are commonly only several to dozens of diamond grains per ton $[7,56,95]$. The reason for these differences is unclear.

${ }^{187} \mathrm{Os} /{ }^{188}$ Os ratios of chromitites are significantly higher in high-Cr chromitites compared to high-Al chromitites. For example, for Dongbo and Purang, the high-Cr chromitites have ${ }^{187}$ Os $/{ }^{188}$ Os compositions varying from 0.128 to 0.133 and 0.123 to 0.132 , respectively, whereas their high-Al chromitites have values ranging from 0.120 to 0.126 and 0.124 to $0.127[62,63,74,94]$. It is noted that compared to the Purang and Dongbo high-Cr chromitites, the Luobusa high-Cr chromitites exhibit generally lower ${ }^{187} \mathrm{Os} /{ }^{188} \mathrm{Os}$ ratios of 0.104-0.127 [72,78,79] (Figure 3). The latter chromitite massif has been interpreted to have been formed by decompression partial melting of garnet and orthopyroxene (Opx) in the SCLM [37,79]. Alternatively, the Luobusa podiform chromitite was produced by mixing primitive asthenospheric $\mathrm{Cr}$-rich melt and boninitic magma, triggering the saturation and crystallization of chromite [96].

\section{Ultra-High-Pressure Minerals in Ophiolites}

The main minerals separated from ophiolitic peridotites and chromitites include native elements (e.g., diamond, Si), carbides, metal alloys, oxides, sulfides, silicates and fluorides $[5,40,97]$. Ophiolite-hosted diamonds are usually light yellow and yellowishgreen (Figure $4 \mathrm{a}-\mathrm{c}$ ), with rare grayish-green or black colors; some may even be colorless. They mainly occur as monocrystals with grain sizes generally ranging from $0.1 \mathrm{~mm}$ to $0.5 \mathrm{~mm}$ (Figure $4 \mathrm{a}-\mathrm{d}$ ). The largest diamond grain discovered so far comes from Dongqiao and has grain size up to $0.7 \mathrm{~mm} \times 0.6 \mathrm{~mm} \times 0.6 \mathrm{~mm}$, weighing $\sim 0.43 \mathrm{mg}$ in total [13]. Diamonds are mostly enhedral and subhedral monocrystals, with minor schistose or polycrystals (Figure $4 \mathrm{~d}$ ) for those ophiolitic in situ diamonds (Figure $4 \mathrm{e}, \mathrm{f}$ ), and grains extracted from the chromitites and peridotites (Figure $4 \mathrm{a}-\mathrm{d}$ ). Morphologically they are characterized by octahedrons, rhombic dodecahedrons and octahedron-cube aggregates. Diamonds with a mixed crystal habit exhibit growth sectors with various levels of darkness and brightness under cathodoluminescence (CL) light (Figure 4g,h) [98]. The bright part commonly represents an octahedral growth sector with a layered growth characteristic, and a dull sector represents a cuboid growth sector $[5,98]$. Locally, irregular corrosion pits or branching etched grooves are observable [4]. Fourier Transform Infrared (FTIR) spectra studies show that the Luobusa diamonds are IaA, mixed IaA-IaB and Ib types [4,36,99-101].
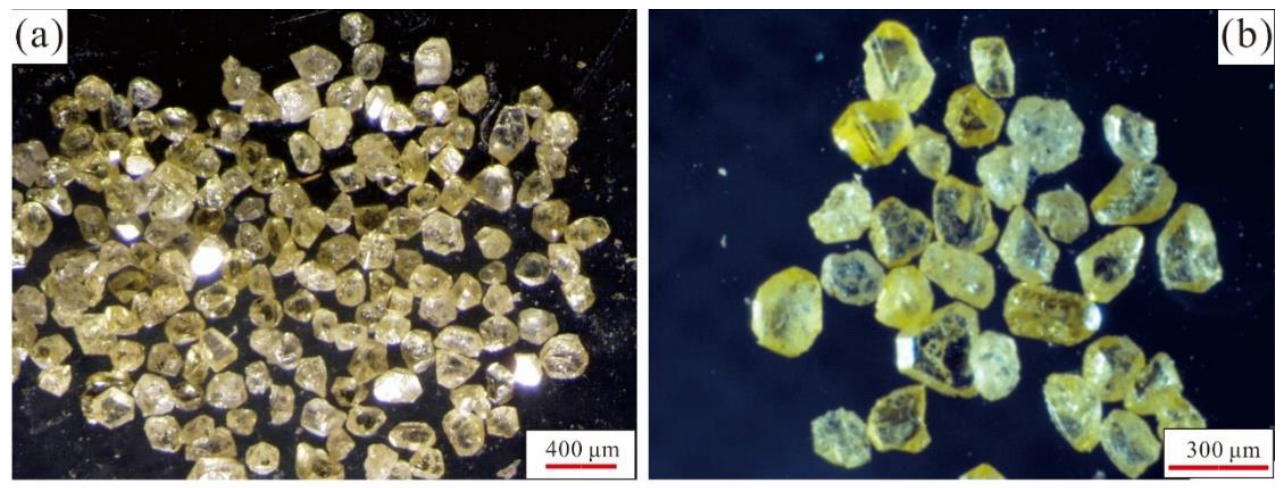

Figure 4. Cont. 

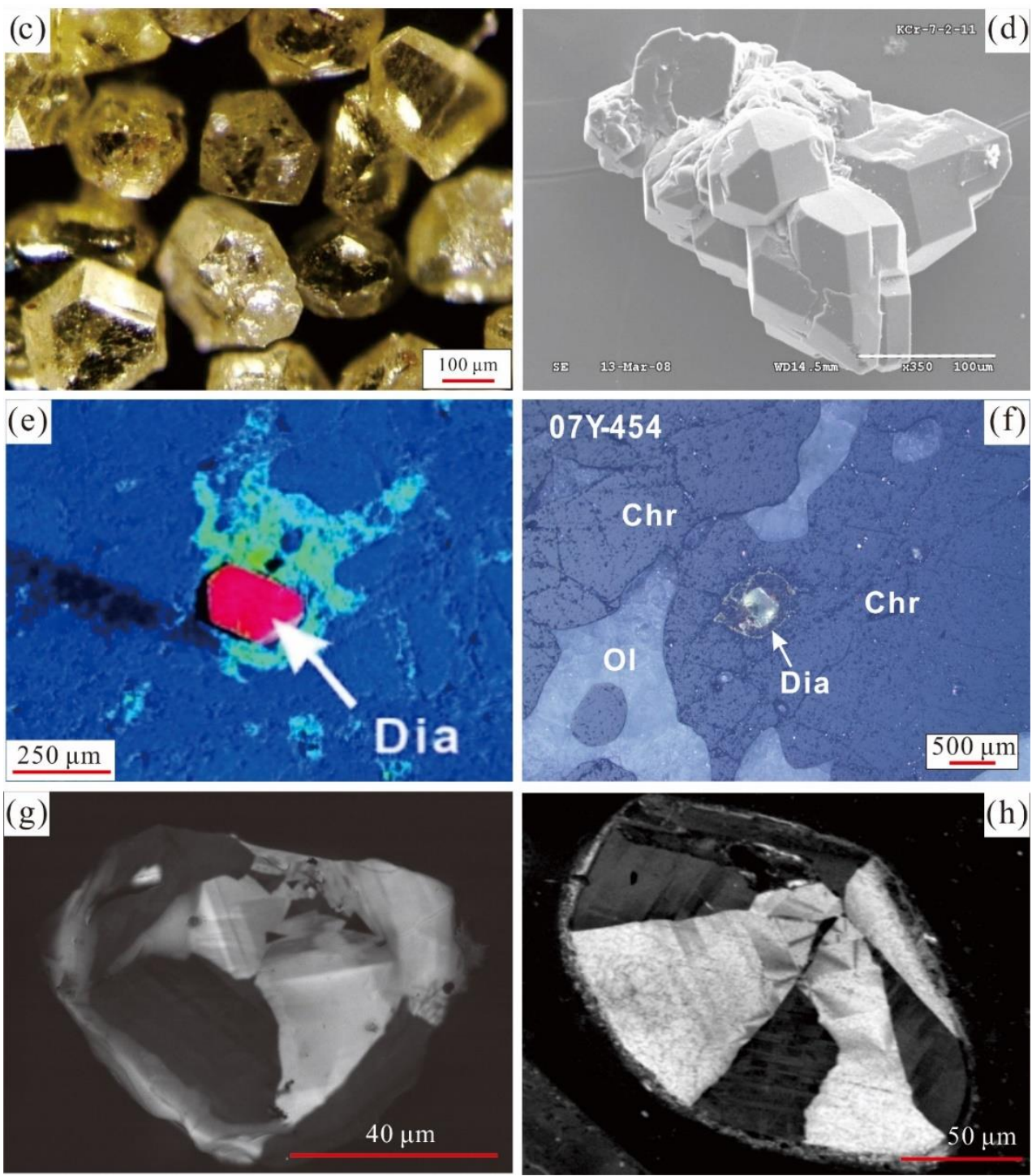

Figure 4. Photomicrographs of ophiolite-hosted diamonds from chromitite and peridotite. (a) Diamonds from the Ray-Iz chromitite, Russia [17]; (b) diamonds from the Pozanti-Karsanti (Aladag) chromitite, Turkey [32]; (c) diamonds from the Ray-Iz chromitite, Russia [24]; (d) backscattered secondary electron image showing polycrystal striations on the diamond surface [20]; (e,f) chromite hosted in an in situ diamond [24]; (f) in situ diamonds hosted by chromitite from the Luobusa and Ray-Iz, respectively [24]; (g) cathodoluminescence (CL) image of a Kalamyo harzburgite-hosted diamond [58]; (h) CL image of a Luobusa harzburgite-hosted diamond.

Diamond is a typical UHP mineral that crystallizes at depths above $150 \mathrm{~km}$ $(\sim 5 \mathrm{GPa})[3,102]$. Ophiolite-hosted diamonds usually have irregular spots or a thin metal film on the surface, e.g., the Ray-Iz diamonds display a $0.01 \mu \mathrm{m}$ film on the surface, whose compositions are dominated by $\mathrm{Zr}$ and $\mathrm{ZrO}$, with minor $\mathrm{Cu}$ sulfides, $\mathrm{NaCl}, \mathrm{SiO}_{2}, \mathrm{Ta}, \mathrm{Fe}$ and $\mathrm{Cr}$ [103]. This metal film is considered to be the product of diamond growth under a high-temperature, high-pressure mantle environment [104]. The microdiamonds are usually associated with other UHP and/or highly reduced minerals, such as elemental $\mathrm{Fe}, \mathrm{Cr}$, Ni and $\mathrm{W}$ and alloys of $\mathrm{SiC}$, OsIr and $\mathrm{FeTi}$, indicating that these minerals were formed in a highly reduced environment [37]. An Os-Ir alloy separated from the Luobusa chromitites contains in situ diamond inclusions of 1-2 $\mu \mathrm{m}$ and an FeTi alloy rimmed by kyanite and coesite that shows pseudomorphs of stishovite, which indicates a formation pressure of $>10 \mathrm{Gpa}(300 \mathrm{~km})$ [17]. Subsequently, a new mineral of qingsongite (c-BN) was discovered in the coesite, which is suggested to form at a comparable pressure to stishovite 
formation [105]. Yamamoto et al. (2009) discovered clinopyroxene (Cpx) and coesite exsolution assemblages in the Luobusa chromitite, which is interpreted to be derived from Ca-ferrite, suggesting a depth of formation of the chromitite in excess of $410 \mathrm{~km} \mathrm{[106].}$ Chromite in the Luobusa chromitites has a high $\mathrm{Fe}^{3+}$ content and abundant primary iron spheres. This combination may represent a high-pressure unbalanced reaction $\left(\mathrm{Fe}^{2+} \rightarrow\right.$ $\mathrm{F}^{\mathrm{e}+}+\mathrm{Fe}^{0}$ ) or a Ca-ferrite structured polymorph under deep mantle conditions [107]. The octahedral silicate mineral separated from Luobusa chromitites displays all Si atoms at octahedral coordination and has a cubic structure thR is similar to that of ringwoodite. This cubic structure is different from the cubic spinel structure of tetrahedral coordination but instead consistent with an inverse-spinel structure. Their equilibrating conditions are generally consistent with the formation of ringwoodite or wadsleyite, which are stable at $\sim 2000{ }^{\circ} \mathrm{C}$ and $\sim 15 \mathrm{GPa}$ [38].

Evidence for UHP conditions is also observed in mantle peridotites. A symplectite texture composed of spinel $+\mathrm{Opx} \pm \mathrm{Cpx}$ was discovered in Luobusa and Purang harzburgites $[38,75,108,109]$. It is interpreted as a product of decompressional decomposition of high-pressure khoharite, indicating a formation depth of above $13.5 \mathrm{Gpa}(\sim 400 \mathrm{~km})$. Moreover, several lines of evidence, including the presence of $\mathrm{C} 2$ /c clinoenstatite and high-pressure $\beta-\mathrm{Mg}_{2} \mathrm{SiO}_{4}$, reported in situ diamond and coesite in the Nidar peridotites in the NW Himalaya [35,110], abundant clinoenstatite as lamellae associated with diopside exsolution in orthoenstatite from the Luobusa mantle peridotites [111], assemblages of carborundum, wustite and native iron inclusions, as well as FeNi and FeCr alloys observed in olivines and chromites in the Luobusa peridotites, all indicate a UHP environment where ophiolitic chromitite and host peridotite formed [112-114].

The other two significant UHP minerals associated with diamond are carborundum (SiC) and corundum. SiC, also called moissanite, is usually light green, pale blue, dark blue and colorless (Figure 5a), with grain sizes of 50-200 $\mu \mathrm{m}$ [5]. Corundum is a common mineral in eclogite and occurs as an unusual inclusion within diamonds [115]. Recent research on corundum in the Luobusa chromitite mine, which is subdivided into, from west to east, Luobusa, Xiangkashan and Kangjinla ore zones in Tibet, has made fruitful and significant progress $[20,57,115,116]$. The Kangjinla corundums are translucent to transparent, mostly pinkish red, and in rare cases colorless, light yellow and light brown. They are characterized by grain sizes of $>200 \mu \mathrm{m}, \mathrm{Al}_{2} \mathrm{O}_{3}$ contents of $96-99.57 \%$ and minor Ti, Fe and $\mathrm{Al}$ oxides [115]. Corundums contain a variety of mineral inclusions, including rutile, native $\mathrm{Ti}$, and $\mathrm{Ti}$ alloys of Ti-N, Ti-Si, Ti-C, Ti-Si-P, Ti-B and Ti-Zr-Al, and REE-bearing (e.g., La, Ce, Nd) silicate minerals and other unknown minerals [57,100] (Figure 5b). Five nano-micron-sized titanium-bearing inclusions called jingsuite $\left(\mathrm{TiB}_{2}\right)$, zhiqinite $\left(\mathrm{TiSi}_{2}\right)$, badengzhuite (TiP), kangjinlaite $\left(\mathrm{Ti}_{11} \mathrm{Si}_{10}\right)$ and wenjiite $\left(\mathrm{Ti}_{10} \mathrm{Si}_{\mathrm{x}} \mathrm{P}_{\mathrm{y}} \mathrm{x}>\mathrm{y}, 6 \leq(\mathrm{x}+\mathrm{y}) \leq 7\right)$ have recently been approved by the IMA [116,117]. These discoveries are significant and are another great breakthrough made on the basis of the discovery of eight new minerals of qingsongite (c$\mathrm{BN})$, qusongite (WC), luobusaite $\left(\mathrm{Fe}_{0.83} \mathrm{Si}_{2}\right)$, yalungite $\left(\left(\mathrm{Cr}_{4} \mathrm{Fe}_{4} \mathrm{Ni}\right)_{9} \mathrm{C}_{4}\right)$, zangboite $\left(\mathrm{TiFeSi}_{2}\right)$, lingzhite $\left(\mathrm{FeSi}_{2}\right)$, naquite $(\mathrm{FeSi})$ and native titanium $[105,118]$. These minerals, stable at different depths of the earth's interior, were formed under highly reducing and UHP conditions. Moreover, petrological experiments indicate that the melting temperature of corundum is higher than that of $\mathrm{Fe}, \mathrm{Ni}$ and $\mathrm{Co}$, and the temperature increases with the increasing pressure, with a maximum up to $25.4 \mathrm{Gpa}$ and $3500 \mathrm{~K}$. Corundum tends to be stable under the $\mathrm{p}-\mathrm{T}$ conditions of the mantle transition zone $(410-670 \mathrm{~km})[119,120]$. In summary, ophiolite-type diamond, corundum and their massive hosting chromitite and mantle peridotite most likely originated at the mantle transition zone or even in the lower mantle. 

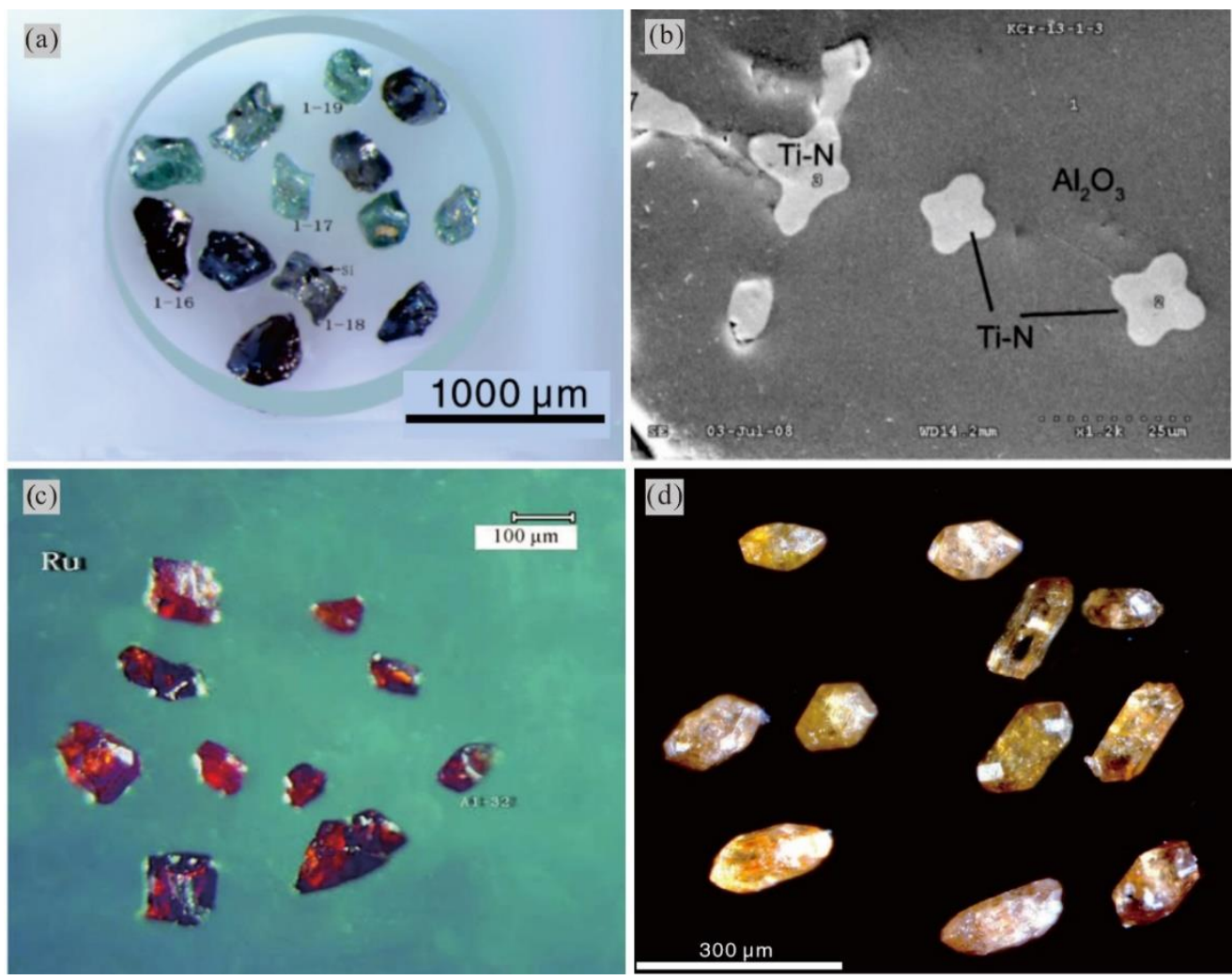

Figure 5. Mantle- and crust-derived minerals associated with diamond in ophiolitic chromitite and peridotite. (a) Moissanites from the Dingqing chromitite [27]; (b) Corundum and its inclusions from the Kangjinla chromitite [115]; (c) Rutiles from the Dangqiong harzburgite [23]; (d) zircons from the Dingqing chromitite [27].

\section{Crustal Minerals in Ophiolites}

In addition to the unusual UHP minerals, crust-derived minerals have been extracted by heavy mineral separation in ophiolitic peridotites and chromitites. These minerals mainly include oxides (e.g., quartz and rutile, Figure 5 c), sulfides (e.g., pyrite, chalcopyrite and arsenopyrite) and silicate minerals (zircon, kyanite, sphene and almandine, etc.). Zircons have been discovered in peridotites and chromitites by many geologists in various ophiolites (Figure 5d). For example, Robinson et al. (2015) implemented in situ U-Pb dating on zircons from the Luobusa and Dongqiao ophiolites in Tibet and the Semail ophiolite in Oman. By secondary ion mass spectroscopy (SIMS), they obtained ages with large variations, i.e., 549-1675 Ma for the Luobusa zircons, 645-2695 Ma for the Dongqiao zircons and 84.3-1411 Ma for the Semail zircons [121]. Yamamoto et al. (2013) reported an even more complex age range of 100-2700 Ma for the inherited zircons from the Luobusa chromitites [122]. Moreover, McGowan et al. (2015) obtained an average zircon U-Pb age of $376 \pm 7 \mathrm{Ma}, \varepsilon \mathrm{Hf}(\mathrm{t})$ values of $9.7 \pm 4.6$ and $\delta^{1}$ values of $4.8-8.2 \%$ for zircons from the Luobusa chromitite [55]. In comparison, inherited zircons from the Horoman peridotites in Japan yielded a wide range of ages between 159 and 3131 Ma with four peaks at 2385, 1890, 1618 and $1212 \mathrm{Ma}$ [33]. The aforementioned inherited zircons have roughly similar inclusions of the crustal minerals: quartz, potash feldspar, muscovite, apatite, ilmenite and rutile, and no mantle minerals such as olivine, pyroxene and spinel. Combined with zircon REE patterns and trace elements abundances and ratios, it can be concluded that these peridotite and chromitite-hosted inherited zircons are of continental origins and mostly derived from granitic rocks [121,122].

Mineral inclusions within diamonds can also be used to reveal details of the environment of their formation and, thus, gain insight into the genesis of the host ophiolitic chromitite and peridotite. Mn-bearing mineral inclusions are commonly observed in 
ophiolite-hosted diamond, e.g., Ni-Mn-Co alloy, Mn-bearing garnet, Mn spinel, Mn olivine, $\mathrm{MnO}$ and elemental $\mathrm{Mn}$, which have been attributed to mainly indicate an ancient shallow origin as a ferromanganese crustal component subducted to over $200 \mathrm{~km}$ in depth [37]. Other inclusions in diamond, including graphite, coesite thought to be pseudomorphic after stishovite, and fluids with $\mathrm{REE}, \mathrm{H}_{2} \mathrm{O}, \mathrm{Cl}, \mathrm{Ca}$ and $\mathrm{Si}$, are comparable with those of crust-derived fluid inclusions enveloped in kimberlitic diamonds [21,97]. The various suites of surficial inclusions indicate that crustal materials have been recycled into the deep mantle.

\section{Isotopic Compositions of Carbon and Nitrogen in Diamond}

The isotopic values of carbon $\left(\delta^{13} \mathrm{C}\right)$ and nitrogen $\left(\delta^{15} \mathrm{~N}\right)$ in ophiolite-hosted diamond also record the recycling of various mantle and surficial materials. Ophiolite-hosted diamonds have negative carbon isotope $\left(\delta^{13} \mathrm{C}\right)$ values of $-29.2 \%$ to $-17.2 \%$ o $[5,6,24,31,33,40,123]$ (Figure 6a). These light $\delta^{13} \mathrm{C}$ values are roughly identical to those of recycled carbon in subducted sediments $(-42 \%$ to $+4.1 \%,-25 \%$ on average) [102], of common organic matter-like $\delta^{13} \mathrm{C}$ compositions ( $-30 \%$ to $-20 \%$ ) [124] and of HPHT synthetic octahedral diamonds ( $-42 \%$ to $-16 \%$ ) [125]. Their shares are also comparable to $\delta^{13} \mathrm{C}$ values from mantle peridotite-type (P-type) diamonds $(-26.4 \%$ to $+0.2 \%$ ) and eclogite-type (E-type) diamonds $(-41.3 \%$ to $+2.7 \%$ ) in kimberlites. They roughly coincide with those of some super-deep continental diamonds from Monastery (-18\%o to $-16 \%$ ) and Jagersfontein $(-24 \%$ to $-16 \%$ ) from the Kaapvaal Craton in South Africa [126] and overlap with those of carbonado ( $-32 \%$ to $-5 \%$ ) as well as those of diamonds $(-30 \%$ o to $-3 \%$ ) hosted in ultra-high-pressure subduction-related metamorphic rocks $[3,123,127]$. In contrast, these light $\delta^{13} \mathrm{C}$ values distinctly differ from those of diamonds in meteorites $(-38.8 \%$ to $-32.5 \%$ ) and coated / fibrous diamonds ( $-8.1 \%$ to $-4.9 \%$ ) that are a special type of monocrystalline-polycrystalline diamond, where monocrystals have been overgrown by a thick, cloudy, polycrystalline coat or rod-blade-shaped diamond laden with microinclusions of fluid $[3,128]$. The aforementioned $\delta^{13} \mathrm{C}$ range of ophiolite-hosted diamonds is much lower than that observed in diamonds from either kimberlites (mainly between $-8 \%$ and $-2 \%$ ) or UHP metamorphic rocks (mainly between $-18 \%$ ond $-5 \%$ ), indicating a natural growth environment at special oceanic mantle conditions.
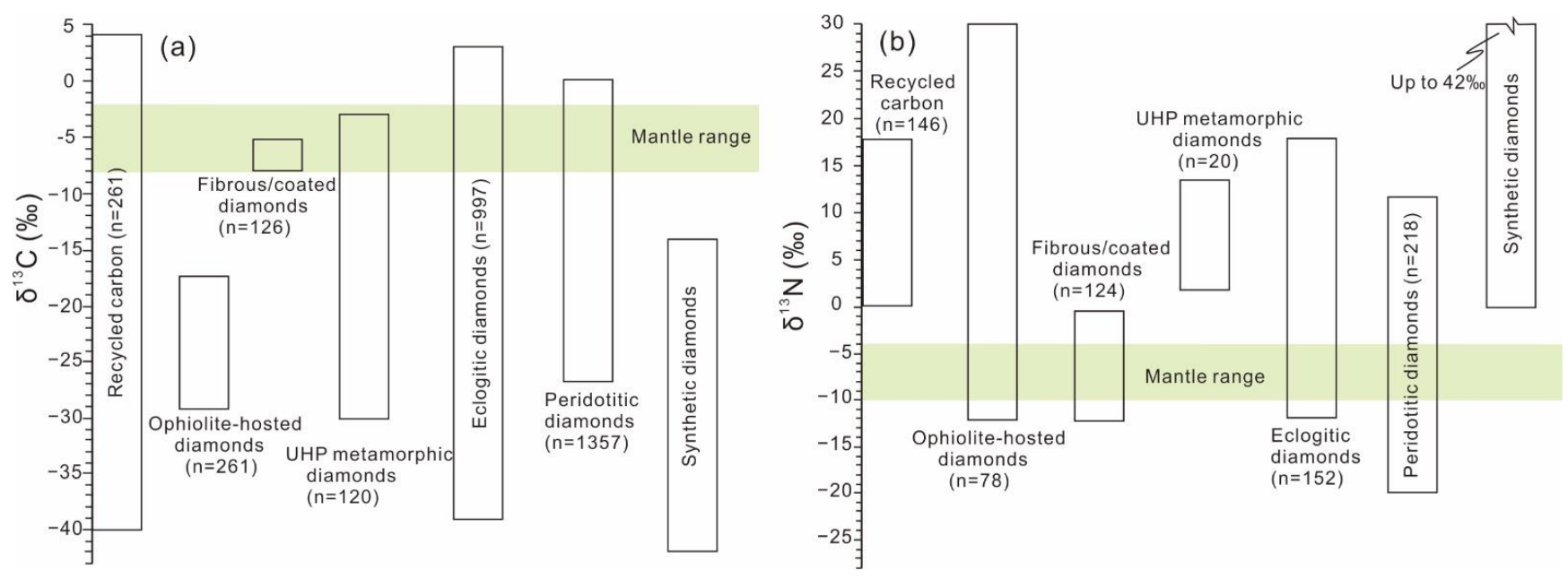

Figure 6. $\delta^{13} \mathrm{C}$ values (a) and $\delta^{15} \mathrm{~N}$ values $(\mathbf{b})$ for various types of diamonds and recycled carbon. Data mainly from $[3,5,102,123,128,129]$.

The ophiolite-hosted diamonds have a large range of $\delta^{15} \mathrm{~N}$ values from $-19.1 \%$ to $+28.6 \%$ (Figure $6 \mathrm{~b}$ ), which is roughly comparable with that of P-type $(-24 \%$ o to $+12 \%$ o and E-type diamonds $(-12 \%$ to $+18 \%$ ) $[5,129]$, and nearly overlap with those of synthetic HPHT diamonds, which show a large range from $-10 \%$ to $+30 \%$ [130]. Conversely, the $\delta^{15} \mathrm{~N}$ values of ophiolite-type diamonds are inconsistent with those of the bulk primi- 
tive mantle ( $-10 \%$ o to $-4 \%$ ) [129], fibrous diamonds $(-12 \%$ to $-0.3 \%$ o $)[5,102,123]$ and metamorphic diamonds (up to $0 \%$ ) [5] (Figure 6b). It is important to note that the octahedral sectors of a large synthetic HPHT diamond were shown to have $\delta^{15} \mathrm{~N}$ values close to the atmospheric value $(0 \%)$, while the cube sectors have higher $\delta^{15} \mathrm{~N}$ values of $+30 \%$ o to $+42 \%$ o $[130,131]$, indicating that $\delta^{15} \mathrm{~N}$ values from different types of diamonds cannot simply be used to discriminate between natural and synthetic diamonds unless the crystal morphologies of the analyzed diamonds are considered [36]. Nevertheless, ophiolite-hosted diamonds generally have high contents of LREEs and are typically enriched in $\mathrm{Ba}, \mathrm{Pb}$, Th and $\mathrm{Eu}$ with typical negative anomalies of $\mathrm{Eu}, \mathrm{Sm}, \mathrm{Yb}$ and $\mathrm{Y}$, and low concentrations of Fe. Their REE and trace element patterns of the ophiolite-hosted diamonds are parallel to those of fibrous diamonds [36,38]. They contain an admixture of nitrogen in an unaggregated form, which is commonly interpreted to indicate that the diamonds did not reside for a long time in the deep mantle [36,132].

\section{Genetic Models of Diamond-Bearing Ophiolite and Chromitite}

The discoveries of UHP minerals (e.g., diamond) and crust-derived minerals (e.g., zircon) in ophiolitic peridotites and chromitites have been gradually recognized. However, genetic models of these unusual minerals and their host chromitites are still under great debate. Four main genetic models are as follows.

Model I: The SCLM carrying low-pressure chromitites formed at a shallow depth was subducted into the deep mantle and then rapidly exhumed to a shallow depth [38]. Podiform chromitites that formed under low-pressure conditions in the shallow part of the SCLM were gradually detached and entered the upper mantle and the mantle transition zone due to the dragging of the subducted oceanic lithosphere (Figure 7a). High-pressure chromitites were then formed, and subducted slabs were metasomatized by carbon-bearing fluids to produce UHP and highly reduced minerals. Subsequently, the subducted slab retreated and gave rise to a shallow extension of the lithospheric mantle and the upward migrating of UHP chromitite to shallow levels beneath MORs and/or forearc and backarc spreading ridges (Figure $7 \mathrm{~b}$ ).
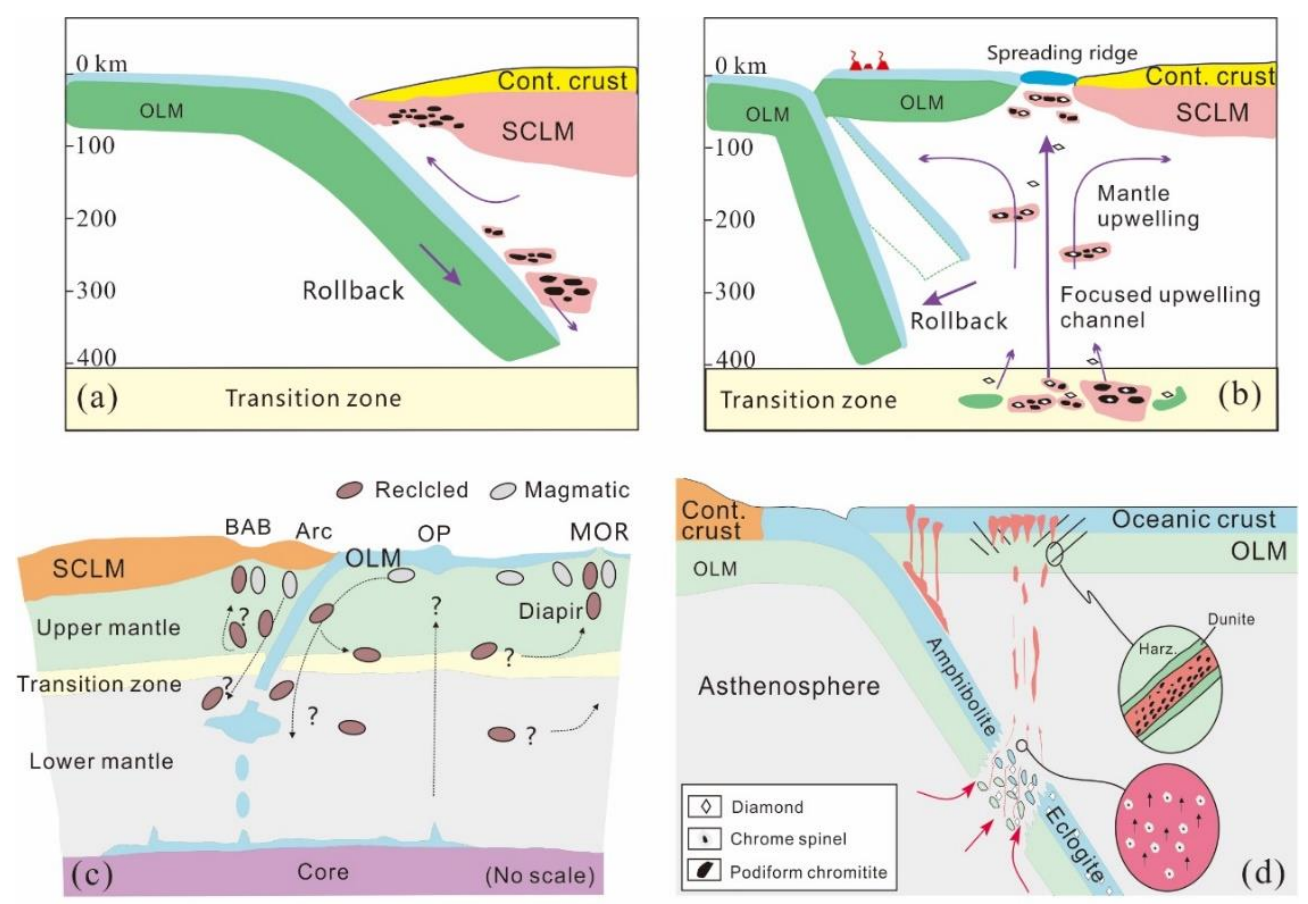

Figure 7. Cont. 


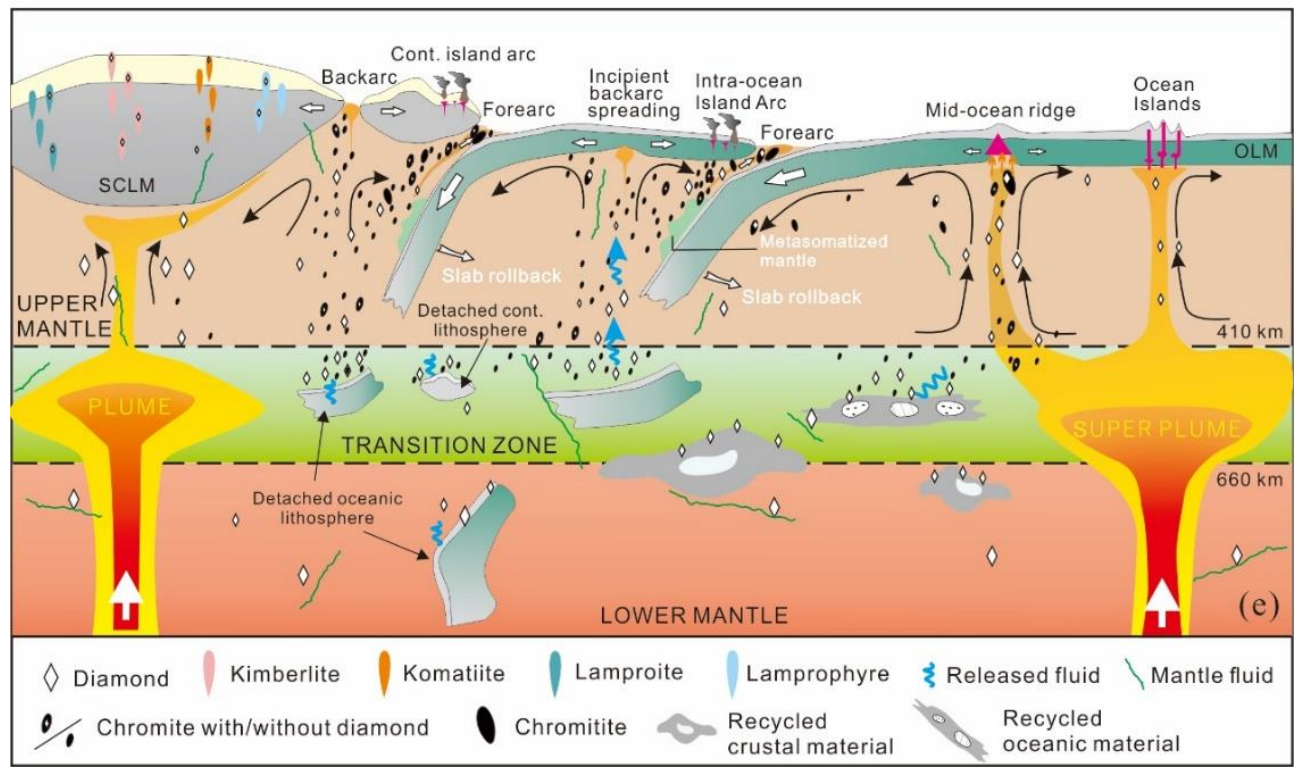

Figure 7. Different genetic models of diamond, peridotite and podiform chromitite in ophiolites. (a,b)—after [38]; (c)—after [91]; (d)—after [92]; (e)—modified after [37,133]. BAB-backarc basin; Cont.—continental; MOR—mid-ocean ridge; OLM-oceanic lithospheric mantle; OP_oceanic plateau; SCLM—subcontinental lithospheric mantle.

This model is mainly based on the research on the Luobusa diamond-bearing chromitite. Re-Os isotopes of the Luobusa mantle peridotites display SCLM signatures [72]. The Re-Os $\mathrm{T}_{\mathrm{RD}}$ ages of the peridotites show a wide range from 0.28 to $3.37 \mathrm{Ga}$. Among the younger ages is the peak Re-Os model age ( $325 \mathrm{Ma}$ ) of Ru-Os-Ir sulfides, and slightly older than that is the peak Re-Os model age (234 Ma) of Os-Ir nuggets in the chromitites [55]. While the minimum age ( 376 Ma) of inherited zircons in chromitite was interpreted as the formation age of chromitite in the shallow part $(<30 \mathrm{~km})$ of the SCLM [55]. The 325-375 Ma may represent the time of ancient SCLM rifting and subsequent the subducted SCLM wedge materials detaching into the transition zone taken place in the Paleo-Tethys Ocean [38]. The age of $234 \mathrm{Ma}$ was thought to represent the early crystalline phase of Os-Ir alloys enclosed in chromitites [72] and, thus, was explained to be the time of the delaminated chromitites being metasomatized within the transition zone $[38,55]$. Two subduction episodes at 150-170 Ma and 120-135 Ma in the Neo-Tethys Ocean may have disturbed the previously subducted lithosphere materials within the mantle transition zone, then excavated the chromitites that have undergone UHP metamorphism to shallow levels via mantle convection (Figure $7 \mathrm{a}, \mathrm{b}$ ). This model illustrates the formation of podiform chromitite and helps to gain insight into the process of crust-derived minerals and mantle-derived UHP and highly reduced minerals, but further consideration of the following issues may be required: (1) Needle-shaped diopside exsolutions are commonly observed in chromites from massive, nodular and disseminated chromitites within the Luobusa and Kangjinla massifs, and they were considered to mean that these three types of chromitites share the same evolution [38]. This point of view is not consistent with the interpretation that massive chromitite-hosted UHP and ultra-reduced minerals formed in the mantle transition zone, while disseminated and nodular chromitites crystallized at shallow depth through the reaction between tholeiitic/boninitic melts and host peridotite $[4,93,97]$. (2) Elements, such as $\mathrm{Si}$ and $\mathrm{Zr}$, incompatible in the parent magma that formed chromite unlikely to crystallize to form zircon. Therefore, it is far-fetched to take $376 \mathrm{Ma}$ as the age of magmatic formation of chromitite that falls within the range of the detrital zircon ages of 100-2700 Ma [121,122]. These detrital zircons with a relatively large age range could have resided for a long time in the mantle transition zone, implying that the process of crustal materials transported to the mantle transition zone is complicated and multi-sourced. 
These subducted materials likely originate from relics of other ancient subducted oceanic lithospheres, such as those of the Panthalassa, Paleo-Asian, Neotethyan, Paleotethyan and even Prototethyan oceans. (3) Re-Os isotopes of chromitites and their host peridotites show SCLM signatures (Figure 3), suggesting that SCLM materials likely have participated in the formation of chromitite. This otherwise feasible model needs to be supported by additional geological evidence before it can be accepted.

Model II: Low-pressure chromitites were initially formed in MOR or SSZ settings at shallow depths of the oceanic mantle lithosphere, then delivered through mantle convection or subduction downward into the mantle transition zone where carbon-bearing fluids that were generated from the dehydration of subducted slabs produced diamonds in a high-pressure and strongly reducing environment. PGE alloys in UHP chromitites may have formed by the desulfuration of PGE-enriched sulfides from low-pressure-type chromitites. Diamond-bearing UHP chromitites are transported to a shallow depth by mantle convection and coexist with newly formed low-pressure chromitites [86,91] (Figure 7c). This model is generally similar to the first one, with the exception that in model II, the low-pressure chromitites formed in a MOR or SSZ setting rather than in the SCLM. Model II argues that the compositions of host peridotites control the formation and scale of podiform chromitite. Podiform chromitite mainly occurs in harzburgite, particularly in moderately depleted harzburgite $\left(\mathrm{Cr}^{\#}=40-60\right)$, while lherzolite and highly depleted harzburgite have almost no or very small-scale chromitite deposits. This model is based on whether Si, Narich hybrid magmas could cause chromite oversaturation. In a lherzolite-magma system, where the Cr-depleted magma mixed with Si-rich magma formed by Opx decomposition, as lherzolite Opx is low in $\mathrm{Cr}^{\#}$, the mixed magma will, at most, be only slightly oversaturated in chromite. In contrast, in highly depleted harzburgite, Opxs have much higher $\mathrm{Cr}^{\#}$, and a melt generated by Opx dissolution will also be much richer in $\mathrm{Cr}$. However, as these depleted harzburgites have a low modal abundance of Opx, the mixed magma can only supply low amounts of $\mathrm{Cr}$ and $\mathrm{Al}$, which is also not favorable for producing large volumes of chromitite. Accordingly, moderately depleted harzburgites in MOR and SSZ, which provide both high enough $\mathrm{Cr}^{\#}$ and high $(\mathrm{Cr}+\mathrm{Al})$ amounts for the precipitation of chromite, are the optimal hosts for large-scale podiform chromitites [86,91].

If the aforementioned arguments are correct, they are significant to guide the exploration of chromitite deposits. The mantle underlying mid-ocean ridges with small spreading rates is dominated by lowly depleted peridotites. According to the statistics on components of modern oceanic mantle periodites, those oceanic lithospheres at low spreading rates are generally dominated by highly enriched lherzolite other than by depleted harzburgite [134]. In contrast, the mantle under the East Pacific Rise has high spreading rates of 128-157 mm/y dominated by harzburgite, where large-scale chromitite deposits are most likely to occur. However, this model does not systematically evaluate the genetic inconsistent relationship between degrees of host mantle peridotite depletion and precipitation of podiform chromitite. Chromitite formation is physicochemical not in equilibrium with their host peridotites. Many disseminated and dyke-shaped chromitites enclosed by thin envelopes of dunite are evidence for their simultaneous formation and a genetic relationship between them. Nevertheless, podiform massive chromitite normally cutting through the foliation of surrounding peridotites and widespread ductile deformation indicates that these chromitites formed much later than their host harzburgites [92]. In addition, high- $\mathrm{Cr}^{\#}$ and high- $\mathrm{Al}^{\#}$ (or low $-\mathrm{Cr}^{\#}$ ) chromitite bodies are widely developed in the same ophiolite massif. For example, both high-Cr $\mathrm{r}^{\#}$ and high- $\mathrm{Al}^{\#}$ chromitite orebodies are observed about 1-2 km apart from each other in the Purang ophiolite in the western segment of the IYSZ $[56,92,94]$. Tectonic discrimination diagrams of $\mathrm{Cr}^{\#}$ versus $\mathrm{TiO}_{2}$ and $\mathrm{Al}_{2} \mathrm{O}_{3}$ versus $\mathrm{TiO}_{2}$ of chromite from various chromitites show that high-Al chromites plot in the field of MORB, although they are not likely derived from MORB magmas, because they display subduction-related signatures evident in depletion of $\mathrm{Sc}, \mathrm{Ti}, \mathrm{V}$ and $\mathrm{Mn}$ in MORB-normalized trace element patterns [92]. Actually, the usefulness of the compositions of chromite as indicators to trace the tectonic settings is questionable because the 
composition of chromite can be modified by fluid/melt-rock interactions in both SSZ and MOR environments [135]. The interpretation of the tectonic setting of chromite formation is still ambiguous and needs further clarification.

Model III: The upwelling of the asthenosphere caused by the rollback, tearing and breakoff of subducted slabs in intra-oceanic subduction zones promoted the formation of UHP chromite-encapsulated diamond [92] (Figure 7d). The continuous subduction of oceanic lithospheric slabs carried oceanic and continental materials into the deep mantle. Subducted slabs successively experiencing greenschist, amphibolite and eclogite facies metamorphism may break off between the boundary of amphibolite and eclogite facies rocks, where a hybrid magma was produced through the mixing of a Cr-rich mafic magma originating from the asthenosphere with melts/fluids derived from subducted slabs. These magmas became more oxidized, more siliceous and more hydrous and rapidly triggered chromite crystallization. Tiny chromite grains suspended in the upward migrating mixed magma passed through the overlying modified mantle wedge, eventually precipitated and accumulated in the uppermost mantle near the MOHO. Some highly reduced and UHP minerals, enclosed in chromite and host mantle peridotites, were transported upwards by the uprising asthenosphere through mantle convection [92] (Figure 7d). The key to this model is that asthenosphere-sourced magmas interacted with melts/fluids from subducted slabs, leading to the formation of a water-rich, high-Mg, Si-rich and chromite-saturated hybrid magma [136]. Zhou et al. (2014) highlight that some of the UHP and highly reduced minerals were enclosed within crystallizing chromites. The large-scale chromitites, typically surrounded by envelopes of dunite, are only found in intra-oceanic SSZ ophiolites, and no major podiform chromitite bodies are developed in MORs or back-arc basins [92].

This model is of significance for understanding the multi-stage magmatic evolution in ophiolite and its relationship with the genesis of chromitite. The following issues must be resolved before this model can be considered valid: (1) can large-scale chromitite deposits form in MOR environments, and can the known small-scale chromitite bodies in modern oceans contain UHP and highly reduced minerals or not? (2) The dunite envelopes of chromitite orebodies are not always observed. For example, the chromitite bodies are in contact with their hosting harzburgites in the Luobusa and Purang ophiolites [93,94]. This observation is seemingly not accounted for by model III. (3) Hydrous mafic magmas are important for the crystallization of chromite and the formation of podiform chromitite. However, $\mathrm{H}_{2} \mathrm{O}$ may not only come from the dehydration of subducted slabs but also from the mantle transition zone, where, at least locally, the water content hosted in wadsleyite and ringwoodite may amount up to about $1 \mathrm{wt} \%$ [137]. (4) The field and petrological differences between UHP chromitite and low-pressure chromitite, as well as their various hosting peridotites, should be studied in more detail.

Model IV: Ophiolite-hosted diamonds crystallized from organic carbon in subducted slab-related fluids/melts; subsequently, they were encapsulated in chromite at different depths between 150 and $660 \mathrm{~km}$, and then these diamond-bearing chromites were transported to a shallow depth under MOR and SSZ environments via mantle convection or mantle plumes $[4,37]$. Subducted materials from oceanic lithospheres that experienced multiple episodes of subduction were incorporated into the mantle transition zone or lower mantle, resulting in the formation of diamonds and other UHP and highly reduced minerals. These minerals were captured and enclosed in high-pressure chromite at the top of the mantle transition zone. Chromitite-hosted diamond and other UHP minerals and some crustal minerals were transported upward to shallow depths by mantle convection through the action of either a mantle plume or channel flow within subduction zones (Figure 7e). Mantle peridotites experienced a widespread rock-melt reaction at shallow levels to create new chromite grains and finally coalesced with UHP chromites to form podiform chromitites in the mantle wedge of an SSZ setting [37].

This model accounts for the widespread existence of UHP and highly reduced minerals in ophiolitic mantle peridotites and chromitites and their dynamic mechanism of upward migration. It suggests that chromitite formation may initially begin within or near 
the mantle transition zone, and thus podiform chromitites commonly record a crust-mantle recycling process $[5,37,138,139]$. Yang et al. (2021) pointed out, however, that there are still many questions remaining in the interpretation of ophiolite-hosted diamond, chromitite and their hosting peridotite formation [37]. For example, (1) how are peridotites containing UHP minerals and recycled crustal materials transported from the mantle transition zone depths to the shallow mantle where they experienced processes of partial melting and metasomatism in various geodynamic settings? Re-Os isotopes of the Luobusa chromitites show no signatures of the lower mantle and core-mantle boundary [72] and do not seem to support the hypothesis of a mantle plume that caused chromitite upward-migration. However, Middle Triassic-Early Cretaceous seamounts widely developed in the IYSZ may point to mantle plume magmatism developed in the Neo-Tethys Ocean [140-142]. Moreover, inclusions in inherited zircons from mantle peridotites and chromitites comprise typical crustal minerals, e.g., quartz, muscovite, biotite, feldspar, ilmenite, rutile and apatite [121,122]. If these zircons were enclosed in chromite grains in the mantle transition zone and upper mantle, they should have preserved some UHP-HP information on the recycling process. Until now, however, no UHP-HP records, such as coesite, garnet, etc., have been reported for the zircons. These records may still be discovered, but other mechanisms must be investigated also. (2) What are the differences between UHP and crustal mineral assemblages in the different ophiolitic belts? These differences could provide important information on the mantle dynamics in various tectonic settings. The amounts of diamonds in ophiolitic chromitites and peridotites located in the same IYSZ are obviously different; for example, over one thousand diamond grains have been extracted from each ton of the Kangjinla massive chromitite and its hosting mantle peridotites in the Luobusa ophiolite [20,57]. In contrast, less than ten to dozens of diamond grains were recovered from the Dongbo, $\mathrm{Pu}$ rang, Dangqiong and Zedang ophiolites along the IYSZ [40,44] (Figure 1b). This variation is likely due to the Yarlung Zangbo Neotethyan oceanic lithosphere having experienced various degrees of mantle plume influence and SCLM contamination in multiple stages of oceanic tectonic evolution. A detailed interpretation remains a subject of debate and ongoing research. (3) What are the carbon sources of ophiolite-hosted diamonds? Their $\delta^{13} \mathrm{C}$ values of $-28.7 \%$ to $-18.0 \%$ fall within the range documented for kimberlite-hosted E-type diamond $(-41.3 \%$ o to $+2.7 \%$ o ) and those diamonds discovered in UHP metamorphic zones $(-30 \%$ to $-3 \%$ ) $[3,5,40,123]$. Combined with Mn-bearing inclusions within diamonds, these light carbon isotopic compositions are considered as evidence of recycled crustal materials in the mantle portions of ophiolites $[5,37,138,139]$. Nevertheless, it is worth noting that these low $\delta^{13} \mathrm{C}$ values also match those of some super-deep diamonds from kimberlites $(-24 \%$ o to $-17 \%$ ) and carbonados that have been linked to komatiites $(-27 \%$ o to $-21 \%$ ) formed in the transition zone and lower mantle [143]. Particularly, ophiolite-hosted diamonds are comparable with those diamonds from primitive chondrites $(-32 \%$ o to $-38 \%$ ) [128]. In view of the lower mantle diamonds being commonly associated with Mn-bearing inclusions [144], carbon sources of the lower mantle and even the outer core cannot be ignored [6].

\section{Controversy and Future Perspectives}

The controversial genetic interpretation of diamond, chromitite and their host peridotite in various ophiolites not only includes the aforementioned four main models but also involves other viewpoints, e.g., UHP and highly reduced mineral assemblages possibly formed by lightning strikes [145], contamination by artificial abrasive materials [146], or formed during serpentinization under low pressure [39]. These issues have recently been hotly debated [147-150]. It is noted that Farré-de-Pablo et al. (2018) reported in situ microdiamonds (diameter $=1-8 \mu \mathrm{m}$ ) in chromite from the Tehuitzingo chromitite in the Acatlán Orogenic Belt in southern Mexico. These diamonds were described as fracturefilling inclusions associated with serpentine, quartz, clinochlore and amorphous carbon. They were considered to have precipitated metastably at low pressure from reduced C-O-H fluids that infiltrated during the serpentinization process of the host peridotite. Massonne 
(2019) argued instead that these diamonds represent contaminations introduced during the preparation of thin sections because five diamond grains are all xenomorphic in shape. Yang et al. (2019) concluded that such microdiamonds are of natural origin because they have been not only observed in serpentinized peridotite but also globally in unserpentinized chromitites and peridotites. They proposed alternatively that microdiamonds associated with some silicates were enclosed by chromite in the deep mantle, as shown in Model IV. Farré-de-Pablo et al. (2019) replied that they had not found UHP minerals other than diamond in the Tehuitzingo chromitites, serpentinized peridotites and other rocks from the Acatlán Complex and claimed that the metamorphism of the Acatlán Complex did not even reach the stability of coesite. They argued that the aforementioned abundant so-called UHP and highly reduced minerals or oriented lamellae of Cpx in chromite developed during cooling and serpentinization rather than under UHP conditions [147].

Actually, several lines of UHP-HP evidence of the Tehuitzingo chromitite bodies and host Acatlán complex have been well studied [151-153]. The Acatlán complex, being the largest Paleozoic metamorphic complex in Mexico, records a continuous evolution from opening, subduction to the final closure of three global Paleozoic oceans, namely Iapetus, the Rheic Ocean and the Paleo-Pacific. It consists of metamorphic lithologies, including eclogite, granulite, blueschist and greenschist facies rocks, as well as phengite-garnet-rutile granitic rocks [153]. The Tehuitzingo eclogite occurs as lenses within serpentinites and meta-argillaceous rocks, which are similar to UHP metamorphic rocks documented in serpentinized peridotites, enclosed eclogite lenses within metapelites in the UHP unit from the southwestern part of the Chinese Tianshan [154]. The rock assemblages suggest that the entire assemblage of chromitite, eclogite and wallrock serpentinite likely underwent a common (ultra)high-pressure metamorphic process [152,153,155]. Moya-Carreras (2017, cited in [153]) discovered UHP metamorphic rocks associated with diamonds and metal alloys in chromitites enclosed by the Xayacatlán serpentinites in the Tehuitzingo area of the Acatlán Complex [153], implying that evidence of UHP metamorphism probably exists in the Tehuitzingo chromitite and host serpentinite.

The Tehuitzingo chromitite orebodies commonly occur as lenses with a length of several meters and a width of $<2 \mathrm{~m}$ in serpentinite. The grain size of diamond enclosed in chromite from massive chromitite is very small $(1-8 \mu \mathrm{m})$, which is much smaller than ophiolite-hosted diamond enclosed in other serpentinites worldwide $(200-500 \mu \mathrm{m})$. The serpentinite is closely interlayered with eclogite and blueschist and locally contains eclogite lenses, indicating that the genesis of the diamond may differ from other ophiolite-type diamonds shown in Figure 1. Alternatively, this diamond may have formed during oceanic lithospheric slab subducted to depths where rocks experienced eclogite facies conditions and microdiamonds crystallized from C-rich fluids produced by metamorphic dehydration of slabs. This process is consistent with the formation of UHP minerals hosted in an ophiolitic podiform chromitite mélange from the Neoarchean metamorphic belt of the Central (Taihang) Orogenic Belt, Northern China [156]. We name this kind of microdiamond oceanic lithospheric subduction-type diamond to distinguish it from diamonds categorized as the mantle transition zone-type discovered in fresh ophiolitic mantle peridotite and chromitite. Both types of diamond are closely related to ophiolite and ascribed to the category of ophiolite-hosted diamond and differ from those of diamonds discovered in kimberlite and continental collision-related UHP metamorphic rock.

In conclusion, as outlined in the previously described four models, a consensus on the deep-mantle (over $150 \mathrm{~km}$ ) genesis of ophiolitic massive chromitite and host peridotite was reached. However, there is still debate on the exact details of ophiolite-hosted diamond and ophiolitic chromitite formation. Potential issues include the source of the chrome, crystallization condition and position of chromite, the transport mechanism of diamond-bearing mantle peridotite and chromitite to a shallow depth, the source of carbon and formation depth of diamond, the mechanism by which crust-derived and mantle-derived materials became trapped by mantle peridotite and chromitite, the subduction zone initiation of plate tectonics, and the accumulation process of chromite as podiform chromitite. Moreover, it is 
unclear whether present-day oceanic mantle peridotite and chromitite have UHP minerals, whether large-scale chromitite deposits develop in modern MOR environments, and why do some ophiolites contain chromitite orebodies while others do not, even in the same suture zone.

In summary, ophiolite-type diamond and other UHP, highly reduced unusual minerals, as well as crustal materials that originated from the mantle transition zone, have been recovered in ophiolitic chromitite and host peridotite. Peridotite and chromitite in ophiolites are not only important mineral reservoirs in the deep earth but also provide fantastic natural samples for understanding the composition of the deep earth, physical and chemical conditions and dynamic processes of recycling of crustal materials to the earth's deep mantle through subduction and their emplacement at shallow depths by mantle convection. These findings, particularly the discovery of new minerals, open a vast new area of research on the genesis of ophiolitic chromitite, tectonic setting of ophiolites in orogenic belts worldwide and crust-mantle materials recycling.

Author Contributions: Conceptualization, F.L. and J.Y.; methodology, F.L. and J.Y.; software, D.L., F.L. and W.W.; validation, F.L., J.Y., D.L. and W.W.; resources, F.L., D.L. and W.W.; data curation, F.L., D.L. and W.W.; writing—original draft preparation, F.L.; writing—review and editing, F.L. and D.L.; supervision, F.L.; project administration, J.Y. and F.L.; funding acquisition, J.Y. and F.L. All authors have read and agreed to the published version of the manuscript.

Funding: This research was funded by grants from the Key Special Project for the Introduced Talents Team of the Southern Marine Science and Engineering Guangdong Laboratory (Guangzhou) (GML2019ZD0201), National Science Foundation of China (41720104009; 92062215), 7th Institute of Geology and Mineral Exploration of Shandong Province (QDKY202007), China Geological Survey (DD20190060) and Key Laboratory of Deep-Earth Dynamics of the Ministry of Natural Resources (J1901-32).

Acknowledgments: We are very grateful to Guest Editor Tingting Gu, Taijin Lu and Assistant Editor Lea Li, Diana Adespei for their help and valuable comments. The two anonymous reviewers are greatly appreciated for their constructive comments and suggestions that greatly improved the manuscript. We also thank Fahui Xiong, Xiaoyan Yu, Yong Zhang, Guanlong Li and Chaofan Zhangfor their helpful suggestions.

Conflicts of Interest: The authors declare no conflict of financial interest or personal relationships that could have appeared to influence the work reported in this paper.

\section{References}

1. Stachel, T.; Harris, J.W. The origin of cratonic diamonds-Constraints from mineral inclusions. Ore Geol. Rev. 2008, 34, 5-32. [CrossRef]

2. Stachel, T.; Harris, J.W.; Muehlenbachs, K. Sources of carbon in inclusion bearing diamonds. Lithos 2009, 112, 625-637. [CrossRef]

3. Shirey, S.B.; Cartigny, P.; Frost, D.J.; Keshav, S.; Nestola, F.; Nimis, P.; Pearson, D.G.; Sobolev, N.V.; Walter, M.J. Diamonds and the Geology of Mantle Carbon. Rev. Mineral. Geochem. 2013, 75, 355-421. [CrossRef]

4. Yang, J.; Robinson, P.T.; Dilek, Y. Diamonds in ophiolites. Elements 2014, 10, 127-130. [CrossRef]

5. Lian, D.; Yang, J. Ophiolite-Hosted Diamond: A New Window for Probing Carbon Cycling in the Deep Mantle. Engineering 2019, 5, 406-420. [CrossRef]

6. Dilek, Y.; Furnes, H. Ophiolite genesis and global tectonics: Geochemical and tectonic fingerprinting of ancient oceanic lithosphere. Geol. Soc. Am. Bull. 2011, 123, 387-411. [CrossRef]

7. Yang, J.S.; Xu, X.Z.; Li, Y.; Li, J.Y.; Ba, D.Z.; Rong, H.; Zhang, Z.M. Diamonds recovered from peridotite of Purang ophiolite in the Yarlung-Zangbo suture of Tibet: A proposal for a new type of diamond occurrence. Acta. Petrol. Mineral. 2011, 27, 3171-3178. (In Chinese with English Abstract)

8. Dresser, J.A. Preliminary Report on the Serpentine and Associated Rocks of Southern Quebec; Memoir-Geological Survey of Canada: Ottawa, ON, Canada, 1913; Volume 1, pp. 1-103.

9. Kaminskiy, F.V.; Vaganov, V.I. Petrological conditions for diamond occurrences in Alpine-type ultrabasic rocks. Int. Geol. Rev. 1977, 19, 1151-1162. [CrossRef]

10. Shilo, A.N.; Kaminskiy, V.F.; Palandzhyan, A.S.; Tilman, M.S.; Tkachenko, A.L. First diamond finds in Alpine-type ultrabasic rocks in the Northeastern USSR. Doki. Akad. Nauk SSSR 1978, 241, 179-182.

11. Fang, Q.S.; Bai, W.J. The discovery of Alpine type diamond bearing ultrabasic intrusions in Xizang (Tibet). Geol. Rev. 1981, 5, 455-457. (In Chinese with English Abstract) 
12. Liang, R.X.; Yang, F.Y.; Fang, Q.S.; Yan, B.G. Diamond-bearing ultramafic rocks in ophiolite belt of Xizang province and its geological significance. Geol. China 1984, 2, 26-28. (In Chinese with English Abstract)

13. Yan, B.G.; Liang, R.X.; Fang, Q.S.; Yang, F.Y.; Yuan, C.Y. Characteristics of diamond and diamond-bearing ultramafic rocks in Qiaoxi and Hongqu, Xizhang. CAGS Bul. Inst. Geol. 1986, 14, 61-118. (In Chinese with English Abstract)

14. Bai, W.; Zhou, M.; Robinson, P.T. Possibly diamond-bearing mantle peridotites and podiform chromitites in the Luobusa and Donqiao ophiolites, Tibet. Can. J. Earth Sci 1993, 30, 1650-1659. [CrossRef]

15. Bai, W.J.; Yang, J.S.; Fang, Q.S.; Yan, B.G.; Shi, R.D. An unusual mantle mineral group in ophiolites of Tibet. Geol. China 2003, 30, 144-150. (In Chinese with English Abstract)

16. Robinson, P.T.; Bai, W.J.; Malpas, J.; Yang, J.S.; Zhou, M.F.; Fang, Q.S.; Hu, X.F.; Cameron, S.; Staudigel, H. Ultra-high pressure minerals in the Luobusa Ophiolite, Tibet, and their tectonic implications. Geol. Soc. 2004, 226, 247-271. [CrossRef]

17. Yang, J.S.; Dobrzhinetskaya, L.; Bai, W.J.; Fang, Q.S.; Robinson, P.T.; Zhang, J.; Green, H.W. Diamond-and coesite-bearing chromitites from the Luobusa ophiolite, Tibet. Geology 2007, 35, 875-878. [CrossRef]

18. Xu, X.Z.; Yang, J.S.; Ba, D.Z.; Chen, S.Y.; Fang, Q.S.; Bai, W.J. Diamond discovered from the Kangjinla chromitite in the Yarlung Zangbo ophiolite belt, Tibet. Acta. Petrol. Mineral. 2008, 24, 1453-1462. (In Chinese with English Abstract)

19. Yang, J.S.; Zhang, Z.M.; Li, T.F.; Li, Z.L.; Ren, Y.F.; Xu, X.Z.; Ba, D.Z.; Bai, W.J.; Fang, Q.S.; Chen, S.Y. Unusual minerals from harzburgite, the host rock of the Luobusa chromite deposit, Tibet. Acta. Petrol. Mineral. 2008, 24, 1445-1452. (In Chinese with English Abstract)

20. Xu, X.Z.; Yang, J.S.; Chen, S.Y.; Fang, Q.S.; Bai, W.J.; Ba, D.Z. Unusual mantle mineral group from chromitite orebody Cr-11 in Luobusa ophiolite of Yarlung-Zangbo suture zone, Tibet. J. Earth Sci.-China 2009, 20, 284-302. [CrossRef]

21. Huang, Z.; Yang, J.; Robinson, P.T.; Zhu, Y.; Xiong, F.; Liu, Z.; Zhang, Z.; Xu, W. The discovery of diamonds in chromitites of the Hegenshan ophiolite, Inner Mongolia, China. Acta. Geol. Sin. (Engl. Ed.) 2015, 89, 341-350.

22. Tian, Y.; Yang, J.; Robinson, P.T.; Xiong, F.; Li, Y.; Zhang, Z.; Liu, Z.; Liu, F.; Niu, X. Diamond Discovered in High-Al Chromitites of the Sartohay Ophiolite, Xinjiang Province, China. Acta. Geol. Sin. (Engl. Ed.) 2015, 89, 332-340.

23. Xiong, F.; Yang, J.; Robinson, P.T.; Xu, X.; Ba, D.; Li, Y.; Zhang, Z.; Rong, H. Diamonds and Other Exotic Minerals Recovered from Peridotites of the Dangqiong Ophiolite, Western Yarlung-Zangbo Suture Zone, Tibet. Acta. Geol. Sin. (Engl. Ed.) 2016, 90, 425-439.

24. Yang, J.; Meng, F.; Xu, X.; Robinson, P.T.; Dilek, Y.; Makeyev, A.B.; Wirth, R.; Wiedenbeck, M.; Cliff, J. Diamonds, native elements and metal alloys from chromitites of the Ray-Iz ophiolite of the Polar Urals. Gondwana Res. 2015, 27, 459-485. [CrossRef]

25. Guo, G.L.; Yang, J.S.; Liu, X.D.; Xu, X.Z.; Zhang, Z.M.; Tian, Y.Z.; Xiong, F.H.; Wu, Y. Implications of unusual minerals in Zedang mantle peridotite, Tibet. Geol. China 2015, 42, 1483-1492. (In Chinese with English Abstract)

26. Xu, X.Z.; Yang, J.S.; Xiong, F.H.; Ba, D.Z.; Zhang, Z.M.; Li, Y. Diamond and other exotic minetals discovered from the Xigaze Mantle peridotite in the Yarlung-Zangbo sutute zone, Tibet. Acta. Geol. Sin. 2018, 92, 1389-1400. (In Chinese with English Abstract)

27. Xiong, F.; Yang, J.; Dilek, Y.; Xu, X.; Zhang, Z. Origin and significance of diamonds and other exotic minerals in the Dingqing ophiolite peridotites, eastern Bangong-Nujiang suture zone, Tibet. Lithosphere 2018, 10, 142-155. [CrossRef]

28. Xiong, F.; Yang, J.; Robinson, P.T.; Dilek, Y.; Milushi, I.; Xu, X.; Zhou, W.; Zhang, Z.; Rong, H. Diamonds Discovered from High-Cr Podiform Chromitites of Bulqiza, Eastern Mirdita Ophiolite, Albania. Acta. Geol. Sin. (Engl. Ed.) 2017, 91, 455-468. [CrossRef]

29. Wu, W.; Yang, J.; Wirth, R.; Zheng, J.; Lian, D.; Qiu, T.; Milushi, I. Carbon and nitrogen isotopes and mineral inclusions in diamonds from chromitites of the Mirdita ophiolite (Albania) demonstrate recycling of oceanic crust into the mantle. Am. Mineral. 2019, 104, 485-500. [CrossRef]

30. Wu, W.; Yang, J.; Ma, C.; Milushi, I.; Lian, D.; Tian, Y. Discovery and Significance of Diamonds and Moissanites in Chromitite within the Skenderbeu Massif of the Mirdita Zone Ophiolite, West Albania. Acta. Geol. Sin. (Engl. Ed.) 2017, 91, 882-897. [CrossRef]

31. Lian, D.; Yang, J.; Wiedenbeck, M.; Dilek, Y.; Rocholl, A.; Wu, W. Carbon and nitrogen isotope, and mineral inclusion studies on the diamonds from the Pozanti-Karsanti chromitite, Turkey. Contrib. Mineral. Petr. 2018, 173, 72. [CrossRef]

32. Lian, D.; Yang, J.; Dilek, Y.; Wu, W.; Zhang, Z.; Xiong, F.; Liu, F.; Zhou, W. Deep mantle origin and ultra-reducing conditions in podiform chromitite: Diamond, moissanite, and other unusual minerals in podiform chromitites from the Pozanti-Karsanti ophiolite, southern Turkey. Am. Mineral. 2017, 102, 1101-1113.

33. Li, Y.; Yang, J.; Nida, K.; Yamamoto, S.; Lin, Y.; Li, Q.; Tian, M.; Kon, Y.; Komiya, T.; Maruyama, S. The mineralogical and chronological evidences of subducted continent material in deep mantle: Diamond, zircon and rutile separated from the Horoman peridotite of Japan. In Proceedings of the AGU Fall Meeting, New Orleans, LA, USA, 11-15 December 2017; AGU: Seattle, WA, USA, 2017; p. DI51C-0418.

34. Taylor, W.R.; Milledge, H.J.; Griffin, B.J.; Nixon, P.H.; Mattey, D.P. Characteristics of microdiamonds from ultramafic massifs in Tibet: Authemic ophialitic diamonds or contamination. In Proceedings of the Sixth International Kimberlite Conference Extended Abstract, Novosibirsk, Russia, 19 September 1995; pp. 623-624.

35. Das, S.; Basu, A.R.; Mukherjee, B.K. In situ peridotitic diamond in Indus ophiolite sourced from hydrocarbon fluids in the mantle transition zone. Geology 2017, 45, 755-758. [CrossRef]

36. Howell, D.; Griffin, W.L.; Yang, J.; Gain, S.; Stern, R.A.; Huang, J.X.; Jacob, D.E.; Xu, X.; Stokes, A.J.; O’Reilly, S.Y.; et al. Diamonds in ophiolites: Contamination or a new diamond growth environment? Earth Planet. Sci. Lett. 2015, 430, 284-295. [CrossRef]

37. Yang, J.; Wu, W.; Lian, D.; Rui, H. Peridotites, chromitites and diamonds in ophiolites. Nat. Rev. Earth Environ. 2021, 2, 198-212. [CrossRef] 
38. Griffin, W.L.; Afonso, J.C.; Belousova, E.A.; Gain, S.E.; Gong, X.; González-Jiménez, J.M.; Howell, D.; Huang, J.; McGowan, N.; Pearson, N.J. Mantle Recycling: Transition Zone Metamorphism of Tibetan Ophiolitic Peridotites and its Tectonic Implications. J. Petrol. 2016, 57, 655-684. [CrossRef]

39. Farré-de-Pablo, J.; Proenza, J.A.; González-Jiménez, J.M.; Garcia-Casco, A.; Colás, V.; Roqué-Rossell, J.; Camprubí, A.; Sánchez-Navas, A. A shallow origin for diamonds in ophiolitic chromitites. Geology 2019, 47, 75-78. [CrossRef]

40. Liu, F.; Yang, J.S.; Lian, D.Y.; Xiong, F.H.; Wu, W.W. Diamonds and other unusual minerals in global ophiolites. Acta. Geol. Sin. 2020, 94, 2588-2605. (In Chinese with English Abstract)

41. Liou, J.G.; Tsujimori, T.; Yang, J.; Zhang, R.Y.; Ernst, W.G. Recycling of crustal materials through study of ultrahigh-pressure minerals in collisional orogens, ophiolites, and mantle xenoliths: A review. J. Asian Earth Sci. 2014, 96, 386-420. [CrossRef]

42. Coleman, R.G. The ophiolite concept evolves. Elements 2015, 10, 82-84.

43. Rollinson, H. Surprises from the top of the mantle transition zone. Geol. Today 2016, 32, 58-64. [CrossRef]

44. Liu, F.; Yang, J.S.; Lian, D.Y.; Li, G.L. Geological features of Neothyan ophiolites in Tibetan Plateau and its tectonic evolution. Acta. Petrol. Mineral. 2020, 36, 2913-2945. (In Chinese with English Abstract)

45. Wu, F.Y.; Wan, B.; Zhao, L.; Xiao, W.J.; Zhu, R.X. Tethyan geodynamics. Acta. Petrol. Mineral. 2020, 36, 1627-1674. (In Chinese with English Abstract)

46. Li, Z.H.; Xu, Z.Q. Dynamics of along-strike transition between oceanic subduction and continental collision: Effects of fluid-melt activity. Acta. Petrol. Mineral. 2015, 31, 3524-3530. (In Chinese with English Abstract)

47. Xu, Z.; Dilek, Y.; Cao, H.; Yang, J.; Robinson, P.; Ma, C.; Li, H.; Jolivet, M.; Roger, F.; Chen, X. Paleo-Tethyan evolution of Tibet as recorded in the East Cimmerides and West Cathaysides. J. Asian Earth Sci. 2015, 105, 320-337. [CrossRef]

48. Metcalfe, I. Gondwana dispersion and Asian accretion: Tectonic and palaeogeographic evolution of eastern Tethys. J. Asian Earth Sci 2013, 66, 1-33. [CrossRef]

49. Dilek, Y.; Furnes, H. Tethyan ophiolites and Tethyan seaways. J. Geol. Soc. Lond. 2019, 176, 899-912. [CrossRef]

50. Dilek, Y. Collision tectonics of the Mediterranean region: Causes and consequences. Spec. Pap.-Geol. Soc. Am. 2006, 409, 1-13.

51. Seltmann, R.; Porter, T.M.; Pirajno, F. Geodynamics and metallogeny of the central Eurasian porphyry and related epithermal mineral systems: A review. J. Asian Earth Sci. 2014, 79, 810-841. [CrossRef]

52. Şengör, A.M.C.; Natal'In, B.A. Turkic-type orogeny and its role in the making of the continental crust. Annu. Rev. Earth Planet. Sci. 1996, 24, 263-337. [CrossRef]

53. Liu, Y.; Li, W.; Feng, Z.; Wen, Q.; Neubauer, F.; Liang, C. A review of the Paleozoic tectonics in the eastern part of Central Asian Orogenic Belt. Gondwana Res. 2017, 43, 123-148. [CrossRef]

54. Chen, Y.; Yang, J.; Xu, Z.; Tian, Y.; Lai, S. Diamonds and other unusual minerals from peridotites of the Myitkyina ophiolite, Myanmar. J. Asian Earth Sci. 2018, 164, 179-193. [CrossRef]

55. McGowan, N.M.; Griffin, W.L.; González-Jiménez, J.M.; Belousova, E.; Afonso, J.C.; Shi, R.; McCammon, C.A.; Pearson, N.J.; O'Reilly, S.Y. Tibetan chromitites: Excavating the slab graveyard. Geology 2015, 43, 179-182. [CrossRef]

56. Xiong, F.; Liu, Z.; Kapsiotis, A.; Yang, J.; Davide, L.; Robinson, P.T. Petrogenesis of lherzolites from the Purang ophiolite, YarlungZangbo suture zone, Tibet: Origin and significance of ultra-high pressure and other 'unusual' minerals in the Neo-Tethyan lithospheric mantle. Int. Geol. Rev. 2019, 61, 2184-2210. [CrossRef]

57. Xu, X.; Yang, J.; Robinson, P.T.; Xiong, F.; Ba, D.; Guo, G. Origin of ultrahigh pressure and highly reduced minerals in podiform chromitites and associated mantle peridotites of the Luobusa ophiolite, Tibet. Gondwana Res. 2015, 27, 686-700. [CrossRef]

58. Liu, F.; Yang, J.; Niu, X.; Dongyang, L.; Xiong, F.; Sein, K. Diamonds in MOR-type and SSZ-type peridotites in eastern Neotethyan ophiolites: A new observation on unusual minerals and continental materials cycling within deep mantle. Lithos 2021, in preparation.

59. Feng, G.; Yang, J.; Niu, X.; Liu, F.; Qiu, T.; Dilek, Y. Formation processes and tectonic implications of mantle peridotites of the Yushigou ophiolite in the North Qilian Orogenic Belt, NW China. Lithos 2021, 400-401, 106430. [CrossRef]

60. Niida, K. Petrology of the Horoman ultramafic rocks in the Hidaka metamorphic belt, Hokkaido, Japan. J. Fac. Sci. Hokkaido Univ. 1984, 21, 197-250.

61. Liu, F.; Yang, J.; Lian, D.; Li, G.; Wu, W. Diamonds first reported from the Josephine ophiolitic peridotites in North America, western cost of the Pacific Ocean. In Proceedings of the International Symposium on Deep Earth Exploration and Practices, Nanjing, China, 26-31 October 2021.

62. Niu, X.; Yang, J.; Dilek, Y.; Xu, J.; Li, J.; Chen, S.; Feng, G.; Liu, F.; Xiong, F.; Liu, Z. Petrological and Os isotopic constraints on the origin of the Dongbo peridotite massif, Yarlung Zangbo Suture Zone, Western Tibet. J. Asian Earth Sci. 2015, 110, 72-84. [CrossRef]

63. Xu, Y.; Liu, J.; Xiong, Q.; Su, B.; Scott, J.M.; Xu, B.; Zhu, D.; Pearson, D.G. The complex life cycle of oceanic lithosphere: A study of Yarlung-Zangbo ophiolitic peridotites, Tibet. Geochim. Cosmochim. Ac. 2020, 277, 175-191. [CrossRef]

64. Lian, D.; Yang, J.; Robinson, P.T.; Liu, F.; Xiong, F.; Zhang, L.; Gao, J.; Wu, W. Tectonic Evolution of the Western Yarlung Zangbo Ophiolitic Belt, Tibet: Implications from the Petrology, Mineralogy, and Geochemistry of the Peridotites. J. Geol. 2016, 124, 353-376. [CrossRef]

65. Feng, G.; Yang, J.; Dilek, Y.; Liu, F.; Xiong, F. Petrological and Re-Os isotopic constraints on the origin and tectonic setting of the Cuobuzha peridotite, Yarlung Zangbo suture zone, southwest Tibet, China. Lithosphere 2018, 10, 95-108. 
66. Büchl, A.; Brügmann, G.E.; Batanova, V.G.; Hofmann, A.W. Os mobilization during melt percolation: The evolution of Os isotope heterogeneities in the mantle sequence of the troodos ophiolite, Cyprus. Geochim. Cosmochim. Acta 2004, 68, 3397-3408. [CrossRef]

67. Shi, R.; Griffin, W.L.; O’Reilly, S.Y.; Huang, Q.; Zhang, X.; Liu, D.; Zhi, X.; Xia, Q.; Ding, L. Melt/mantle mixing produces podiform chromite deposits in ophiolites: Implications of Re-Os systematics in the Dongqiao Neo-tethyan ophiolite, northern Tibet. Gondwana Res. 2012, 21, 194-206. [CrossRef]

68. Rudnick, R.L.; Walker, R.J. Interpreting ages from Re-Os isotopes in peridotites. Lithos 2009, 112, 1083-1095. [CrossRef]

69. Becker, H.; Dale, C.W. Re-Pt-Os Isotopic and Highly Siderophile Element Behavior in Oceanic and Continental Mantle Tectonites. Rev. Mineral. Geochem. 2016, 81, 369-440. [CrossRef]

70. Shirey, S.B.; Walker, R.J. The Re-Os isotope system in cosmochemistry and hightemperature geochemistry. Annu. Rev. Earth Planet. Sci. 1998, 26, 423-500. [CrossRef]

71. Widom, E. Ancient mantle in a modern plume. Nature 2002, 420, 281-282. [CrossRef]

72. Shi, R.; Alard, O.; Zhi, X.; O’Reilly, S.Y.; Pearson, N.J.; Griffin, W.L.; Zhang, M.; Chen, X. Multiple events in the Neo-Tethyan oceanic upper mantle: Evidence from Ru-Os-Ir alloys in the Luobusa and Dongqiao ophiolitic podiform chromitites, Tibet. Earth Planet. Sci. Lett. 2007, 261, 33-48. [CrossRef]

73. Li, J.Y. Genesis of Mantle Peridotite in the Luobusa, Tibet-The Study of Scientific Drilling Core (LSD-1). Ph.D. Thesis, Chinese Academy of Geological Science, Beijing, China, 2012; pp. 1-179.

74. Liu, C.; Wu, F.; Chu, Z.; Ji, W.; Yu, L.; Li, J. Preservation of ancient Os isotope signatures in the Yungbwa ophiolite (southwestern Tibet) after subduction modification. J. Asian Earth Sci. 2012, 53, 38-50. [CrossRef]

75. Gong, X.; Shi, R.; Griffin, W.L.; Huang, Q.; Xiong, Q.; Chen, S.; Zhang, M.; O’Reilly, S.Y. Recycling of ancient subduction-modified mantle domains in the Purang ophiolite (southwestern Tibet). Lithos 2016, 262, 11-26. [CrossRef]

76. Liu, T.; Wu, F.; Liu, C.; Zhang, C.; Ji, W.; Xu, Y. Reconsideration of Neo-Tethys evolution constrained from the nature of the Dazhuqu ophiolitic mantle, southern Tibet. Contrib. Mineral. Petr. 2019, 174, 23. [CrossRef]

77. Lai, S.; Yang, J.; Dilek, Y.; Xiong, F.; Jiang, R.; Chen, Y. Petrological and Os Isotopic Characteristics of Zedong Peridotites in the Eastern Yarlung-Zangbo Suture in Tibet. Acta. Geol. Sin. (Engl. Ed.) 2018, 92, 442-461. [CrossRef]

78. Zhang, C.; Liu, C.; Liu, T.; Wu, F. Evolution of mantle peridotites from the Luobusa ophiolite in the Tibetan Plateau: Sr-Nd-Hf-Os isotope constraints. Lithos 2020, 362, 105477. [CrossRef]

79. Shi, R.D.; Huang, Q.S.; Liu, D.L.; Fan, S.Q.; Zhang, X.R.; Ding, L. Recycling of Ancient Sub-Continental Lithospheric Mantle Constraints on the Genesis of the Ophiolitic Podiform Chromitites. Geol. Rev. 2012, 58, 643-652. (In Chinese with English Abstract)

80. Huang, Q.S.; Shi, R.D.; Ding, B.H.; Liu, D.L.; Zhang, X.R.; Fan, S.Q.; Zhi, X.C. Re-Os isotopic evidence of MOR-type ophiolite from the Bangong Co for the opening of Bangong-Nujiang Tethys Ocean. Acta. Petrol. Mineral. 2012, 31, 465-478. (In Chinese with English Abstract)

81. Huang, X.; Shi, R.; Gong, X.; Huang, Q.; Griffin, W.L.; O’Reilly, S.Y.; Chen, S. Oceanization of the subcontinental lithospheric mantle recorded in the Yunzhug ophiolite, Central Tibetan Plateau. Lithos 2020, 370, 105612. [CrossRef]

82. Huang, Q.; Shi, R.; O'Reilly, S.Y.; Griffin, W.L.; Zhang, M.; Liu, D.; Zhang, X. Re-Os isotopic constraints on the evolution of the Bangong-Nujiang Tethyan oceanic mantle, Central Tibet. Lithos 2015, 224, 32-45. [CrossRef]

83. Thayer, T.P. Principal features and origin of podiform chromite deposits, and some observations on the Guelman-Soridag District, Turkey. Econ. Geol. 1964, 59, 1497-1524. [CrossRef]

84. Cameron, G.N. Chromite in the central sector of the eastern Bushveld Complex, South Africa. Am. Mineral. 1977, 62, 1082-1096.

85. Lago, B.L.; Michel, R.; Adolphe, N. Podiform Chromite Ore Bodies: A Genetic Model. J. Petrol. 1982, 23, 103-125. [CrossRef]

86. Arai, S.; Miura, M. Formation and modification of chromitites in the mantle. Lithos 2016, 264, 277-295. [CrossRef]

87. Cassard, D.; Nicolas, A.; Rabinovitch, M.; Moutte, J.; Leblanc, M.; Prinzhofer, A. Structural classification of chromite pods in southern New Caledonia. Econ. Geol. 1981, 76, 805-831. [CrossRef]

88. Leblanc, M.; Nicolas, A. Ophiolitic chromitites. Int. Geol. Rev. 1992, 34, 653-686. [CrossRef]

89. Li, G.L.; Yang, J.S.; Bo, R.Z.; Rui, H.C.; Xiong, F.H.; Guo, T.F.; Zhang, C.J. Dingqing ophiolite chromite in the eastern segment of Bangong Co-Nujiang suture zone, Tibet: Occurrence characteristics and classifications. Geol. China 2019, 46. 1-20, (In Chinese with English Abstract)

90. Dick, H.J.B.; Bullen, T. Chromian spinel as a petrogenetic indicator in abyssal and alpine-type peridotites and spatially associated lavas. Contrib. Miner. Petr. 1984, 86, 54-76. (In Chinese with English Abstract) [CrossRef]

91. Arai, S. Conversion of low-pressure chromitites to ultrahigh-pressure chromitites by deep recycling: A good inference. Earth Planet. Sci. Lett. 2013, 379, 81-87. [CrossRef]

92. Zhou, M.; Robinson, P.T.; Su, B.; Gao, J.; Li, J.; Yang, J.; Malpas, J. Compositions of chromite, associated minerals, and parental magmas of podiform chromite deposits: The role of slab contamination of asthenospheric melts in suprasubduction zone environments. Gondwana Res. 2014, 26, 262-283. [CrossRef]

93. Xiong, F.; Yang, J.; Robinson, P.T.; Xu, X.; Liu, Z.; Li, Y.; Li, J.; Chen, S. Origin of podiform chromitite, a new model based on the Luobusa ophiolite, Tibet. Gondwana Res. 2015, 27, 525-542. [CrossRef]

94. Xiong, F.; Yang, J.; Robinson, P.T.; Xu, X.; Liu, Z.; Zhou, W.; Feng, G.; Xu, J.; Li, J.; Niu, X. High-Al and high-Cr podiform chromitites from the western Yarlung-Zangbo suture zone, Tibet: Implications from mineralogy and geochemistry of chromian spinel, and platinum-group elements. Ore. Geol. Rev. 2017, 80, 1020-1041. [CrossRef] 
95. Xu, X.Z.; Yang, J.S.; Ba, D.Z.; Zhang, Z.M.; Xiong, F.H.; Li, Y. Diamond discovered from the Dongbo mantle peridotite in the Yarlung Zangbo suture zone, Tibet. Geol. China 2015, 42, 1471-1482. (In Chinese with English Abstract)

96. Ruan, T.; Zhong, H.; Zhu, J.; Bai, Z. The formation of giant podiform chromitite by asthenospheric melts in supra-subduction zone environments. Nat. Commun. 2021, submitted.

97. Yang, J.; Robinson, P.T.; Dilek, Y. Diamond-bearing ophiolites and their geological occurrence. Episodes 2015, 38, 344-364. [CrossRef]

98. Sunagawa, I. Growth and morphology of diamond crystals under stable and metastable contitions. J. Cryst. Growth 1990, 99, 1156-1161. [CrossRef]

99. Li, J.J.; Fan, C.X.; Chen, Y.F.; Liu, X.S.; Wang, Y.; Shan, G.Q.; Li, T.; Li, G.H.; Ding, X.Y.; Zhao, X.X.; et al. Review for Frequent Characteristics of Diamond UV-Vis-MIR Spectra. J. Synth. Cryst. 2021, 50, 158-166. (In Chinese with English Abstract)

100. Xu, X.; Cartigny, P.; Yang, J.; Dilek, Y.; Xiong, F.; Guo, G. Fourier transform infrared spectroscopy data and carbon isotope characteristics of the ophiolite-hosted diamonds from the Luobusa ophiolite, Tibet, and Ray-Iz ophiolite, Polar Urals. Lithosphere 2018, 10, 156-169. [CrossRef]

101. Rong, H.; Yang, J.S.; Zhang, Z.M.; Xu, X.Z. A preliminary study of FT-IR on the diamonds from the Luobusa chromitites of Tibet and the eclogite of CCSD-MH, China. Acta. Petrol. Mineral. 2013, 29, 1861-1866. (In Chinese with English Abstract)

102. Cartigny, P. Stable Isotopes and the Origin of Diamond. Elements 2005, 1, 79-84. [CrossRef]

103. Yang, J.S.; Xu, X.Z.; Bai, W.J.; Zhang, Z.M.; Rong, H. Features of diamond in ophiolite. Acta. Petrol. Mineral. 2014, 30, 2113-2124, (In Chinese with English Abstract).

104. Makeev, A.B.; Kriulina, G.Y. Metal films on the surfaces and within diamond crystals from Arkhangelskaya and Yakutian diamond provinces. Geol. Ore Deposit. 2012, 54, 663-673. [CrossRef]

105. Dobrzhinetskaya, L.F.; Wirth, R.; Yang, J.; Hutcheon, I.D.; Weber, P.K.; Green, H.N. High-pressure highly reduced nitrides and oxides from chromitite of a Tibetan ophiolite. Proc. Natl. Acad. Sci. USA 2009, 106, 19233-19238. [CrossRef]

106. Yamamoto, S.; Komiya, T.; Hirose, K.; Maruyama, S. Coesite and clinopyroxene exsolution lamellae in chromites: In-situ ultrahighpressure evidence from podiform chromitites in the Luobusa ophiolite, southern Tibet. Lithos 2009, 109, 314-322. [CrossRef]

107. Rohrbach, A.; Ballhaus, C.; Golla Schindler, U.; Ulmer, P.; Kamenetsky, V.S.; Kuzmin, D.V. Metal saturation in the upper mantle. Nature 2007, 449, 456-458. [CrossRef] [PubMed]

108. Satsukawa, T.; Griffin, W.L.; Piazolo, S.; O'Reilly, S.Y. Messengers from the deep: Fossil wadsleyite-chromite microstructures from the Mantle Transition Zone. Sci. Rep. 2015, 5, 16484. [CrossRef]

109. Gong, X.H.; Shi, R.D.; Xu, J.F.; Huang, Q.S.; Huang, X.X.; Su, B.X. “Garnet” Lherzolites in the Purang Ophiolite, Tibet: Evidence for Exhumation of Deep Oceanic Lithospheric Mantle. Geophys. Res. Lett. 2020, 47, e2019GL086101. [CrossRef]

110. Das, S.; Mukherjee, B.K.; Basu, A.R.; Sen, K. Peridotitic minerals of the Nidar Ophiolite in the NW Himalaya: Sourced from the depth of the mantle transition zone and above. Geol. Soc. 2015, 412, 271-286. [CrossRef]

111. Zhang, R.Y.; Shau, Y.H.; Yang, J.S.; Liou, J.G. Discovery of clinoenstatite in the Luobusa ophiolitic mantle peridotite recovered from a drill hole, Tibet. J. Asian Earth Sci. 2017, 145, 605-612. [CrossRef]

112. Huang, M.; Yang, J.; Powell, R.; Mo, X. High-pressure metamorphism of serpentinized chromitite at Luobusha (southern Tibet). Am. J. Sci. 2014, 314, 400-433. [CrossRef]

113. Liang, F.; Xu, Z.; Zhao, J. In-situ Moissanite in Dunite: Deep Mantle Origin of Mantle Peridotite in Luobusa Ophiolite, Tibet. Acta. Geol. Sin. (Engl. Ed.) 2014, 88, 517-529. [CrossRef]

114. Zhang, R.Y.; Yang, J.; Ernst, W.G.; Jahn, B.; Iizuka, Y.; Guo, G. Discovery of in situ super-reducing, ultrahigh-pressure phases in the Luobusa ophiolitic chromitites, Tibet: New insights into the deep upper mantle and mantle transition zone. Am. Mineral. 2016, 101, 1285-1294. [CrossRef]

115. Xu, X.Z.; Yang, J.S.; Guo, G.L.; Xiong, F.H. Mineral inclusions in corundum from chromitites in the Kangjinla chromite deposit, Tibet. Acta. Petrol. Mineral. 2013, 29, 1867-1877, (In Chinese with English Abstract).

116. Miyawaki, R.; Hatert, F.; Pasero, M.; Mills, S.J. IMA Commission on New Minerals, Nomenclature and Classification (CNMNC)— Newsletter 52. Eur. J. Mineral. 2020, 32, 1-11. [CrossRef]

117. Miyawaki, R.; Hatert, F.; Pasero, M.; Mills, S.J. IMA Commission on New Minerals, Nomenclature and Classification (CNMNC)Newsletter 61. Eur. J. Mineral. 2021, 33, 299-304. [CrossRef]

118. Li, G.W.; Shi, N.C.; Bai, W.J.; Fang, Q.S.; Xiong, M. Seven new intermetallic minerals found in Luobusa, Tibet, China. Acta. Mieral. Sin. 2015, 35, 13-18.

119. Boehler, R. High-pressure experiments and the phase diagram of lower mantle and core materials. Rev. Geophys. 2000, 38, 221-245. [CrossRef]

120. Shen, G.; Lazor, P. Measurement of melting temperatures of some minerals under lower mantle pressures. J. Geophys. Res. Atmos. 1995, 100, 17699. [CrossRef]

121. Robinson, P.T.; Trumbull, R.B.; Schmitt, A.; Yang, J.; Li, J.; Zhou, M.; Erzinger, J.; Dare, S.; Xiong, F. The origin and significance of crustal minerals in ophiolitic chromitites and peridotites. Gondwana Res. 2015, 27, 486-506. [CrossRef]

122. Yamamoto, S.; Komiya, T.; Yamamoto, H.; Kaneko, Y.; Terabayashi, M.; Katayama, I.; Iizuka, T.; Maruyama, S.; Yang, J.; Kon, Y. Recycled crustal zircons from podiform chromitites in the Luobusa ophiolite, southern Tibet. Isl. Arc 2013, 22, 89-103. [CrossRef]

123. Lian, D.Y.; Yang, J.S.; Liu, F.; Wu, W.W. Diamond Classification, Compositional Characteristics, and Research Progress: A Review. Earth Sci. 2019, 44, 3409-3453. 
124. Schidlowski, M. Carbon isotopes as biogeochemical recorders of life over 3.8 Ga of Earth history: Evolution of a concept. Precambrian Res. 2001, 106, 117-134. [CrossRef]

125. Zhu, Z.Y.; Xu, Y.M.; Zhou, W. In-situ Carbon Isotope and Cathodoluminescence Characteristics of High Temperature and High Pressure Synthetic Diamond. Acta. Geosci. Sin. 2020, 41, 714-722. (In Chinese with English Abstract)

126. Palot, M.; Pearson, D.G.; Stachel, T.; Stern, R.A.; Le Pioufle, A.; Gurney, J.J.; Harris, J.W. The transition zone as a host for recycled volatiles: Evidence from nitrogen and carbon isotopes in ultra-deep diamonds from Monastery and Jagersfontein (South Africa). Chem. Geol. 2017, 466, 733-749. [CrossRef]

127. Cartigny, P.; Palot, M.; Thomassot, E.; Harris, J.W. Diamond Formation: A Stable Isotope Perspective. Annu. Rev. Earth Planet. Sci. 2014, 42, 699-732. [CrossRef]

128. Russell, S.S.; Arden, J.W.; Pillinger, C.T. A carbon and nitrogen isotope study of diamond from primitive chondrites. Meteorit. Planet Sci. 1996, 31, 343-355. [CrossRef]

129. Jia, Y.; Kerrich, R. N-isotope composition of the primitive mantle compared to diamonds. Lithos 2015, 233, 131-138. [CrossRef]

130. Reutsky, V.N.; Harte, B.; Eimf, B.; Palyanov, Y.N. Monitoring diamond crystal growth, a combined experimental and SIMS study. Eur. J. Mineral. 2008, 20, 365-374. [CrossRef]

131. Boyd, S.R.; Pillinger, C.T.; Milledge, H.J.; Mendelssohn, M.J.; Seal, M. Fractionation of nitrogen isotopes in a synthetic diamond of mixed crystal habit. Nature 1988, 331, 604-607. [CrossRef]

132. Galimov, E.M.; Kaminsky, F.V. Diamond in the Oceanic Lithosphere. Volcanic Diamonds and Diamonds in Ophiolites. Geochem. Int. 2021, 59, 1-11. [CrossRef]

133. Dilek, Y.; Yang, J. Ophiolites, diamonds, and ultrahigh-pressure minerals: New discoveries and concepts on upper mantle petrogenesis. Lithosphere 2018, 10, 3-13. [CrossRef]

134. Warren, J.M. Global variations in abyssal peridotite compositions. Lithos 2016, 248, 193-219. [CrossRef]

135. Gamal El Dien, H.; Arai, S.; Doucet, L.; Li, Z.; Kil, Y.; Fougerouse, D.; Reddy, S.M.; Saxey, D.W.; Hamdy, M. Cr-spinel records metasomatism not petrogenesis of mantle rocks. Nat. Commun. 2019, 10, 5103. [CrossRef]

136. Zhou, M.F.; Robinson, P.T.; Malpas, J.; Edwards, S.J.; Qi, L. REE and PGE geochemical constraints on the formation of dunites in the Luobusa Ophiolite, Southern Tibet. J. Petrol. 2005, 46, 615-639. [CrossRef]

137. Pearson, D.G.; Brenker, F.E.; Nestola, F.; McNeill, J.; Nasdala, L.; Hutchison, M.T.; Matveev, S.; Mather, K.; Silversmit, G.; Schmitz, S.; et al. Hydrous mantle transition zone indicated by ringwoodite included within diamond. Nature 2014, 507, 221-224. [CrossRef] [PubMed]

138. Wu, W.; Yang, J.; Lian, D.; Rui, H. New Concepts in Ophiolites, Oceanic Lithosphere and Podiform Chromites. In Encyclopedia of Geology, 2nd ed.; Alderton, D., Elias, S.A., Eds.; Academic Press: Oxford, MI, USA, 2021; pp. 968-993.

139. Yang, J.S.; Lian, D.Y.; Wu, W.W.; Rui, H.C. Recycling of subducted crust in deep mantle: A new research orientation to earth dynamics. Acta. Geol. Sin. 2021, 95, 42-63. (In Chinese with English Abstract)

140. Zheng, H.; Huang, Q.; Kapsiotis, A.; Lenaz, D.; Velicogna, M.; Xu, C.; Cheng, C.; Xia, B.; Liu, W.; Xiao, Y.; et al. Coexistence of MORB- and OIB-like dolerite intrusions in the Purang ultramafic massif, SW Tibet: A paradigm of plume-influenced MOR-type magmatism prior to subduction initiation in the Neo-Tethyan lithospheric mantle. GSA Bull. 2019, 131, 1276-1294. [CrossRef]

141. Liu, F.; Dilek, Y.; Yang, J.; Lian, D.; Li, G.; Wu, Y. A middle Triassic seamount within the western Yarlung Zangbo suture zone, Tibet: The earliest seafloor spreading record of Neotethys to the North of East Gondwana. Lithos 2021, 388, 106062. [CrossRef]

142. Liu, F.; Yang, J.; Dilek, Y.; Xu, Z.; Xu, X.; Liang, F.; Chen, S.; Lian, D. Geochronology and geochemistry of basaltic lavas in the Dongbo and Purang ophiolites of the Yarlung-Zangbo Suture zone: Plume-influenced continental margin-type oceanic lithosphere in southern Tibet. Gondwana Res. 2015, 27, 701-718. [CrossRef]

143. Cartigny, P. Mantle-related carbonados? Geochemical insights from diamonds from the Dachine komatiite (French Guiana). Earth Planet. Sci. Lett. 2010, 296, 329-339. [CrossRef]

144. Kaminsky, F. Mineralogy of the lower mantle: A review of 'super-deep'mineral inclusions in diamond. Earth-Sci. Rev. 2012, 110, 127-147. [CrossRef]

145. Ballhaus, C.; Wirth, R.; Fonseca, R.O.C.; Blanchard, H.; Pröll, W.; Bragagni, A.; Nagel, T.; Schreiber, A.; Dittrich, S.; Thome, V.; et al. Ultra-high pressure and ultra-reduced minerals in ophiolites may form by lightning strikes. Geochem. Perspect. Lett. 2017, 5, 42-46. [CrossRef]

146. Litasov, K.D.; Kagi, H.; Bekker, T.B. Enigmatic super-reduced phases in corundum from natural rocks: Possible contamination from artificial abrasive materials or metallurgical slags. Lithos 2019, 340-341, 181-190. [CrossRef]

147. Farré-de-Pablo, J.; Proenza, J.A.; González-Jiménez, J.M.; Garcia-Casco, A.; Colás, V.; Roqué-Rosell, J.; Camprubí, A.; Sánchez-Navas, A. A shallow origin for diamonds in ophiolitic chromitites: REPLY. Geology 2019, 47, e477-e478. [CrossRef]

148. Yang, J.; Lian, D.; Robinson, P.T.; Qiu, T.; Xiong, F.; Wu, W. A shallow origin for diamonds in ophiolitic chromitites: COMMENT. Geology 2019, 47, e475. [CrossRef]

149. Massonne, H. A shallow origin for diamonds in ophiolitic chromitites: COMMENT. Geology 2019, 47, e476. [CrossRef]

150. Yang, J.; Simakov, S.K.; Moe, K.; Scribano, V.; Lian, D.; Wu, W. Comment on "Comparison of enigmatic diamonds from the tolbachik arc volcano (Kamchatka) and Tibetan ophiolites: Assessing the role of contamination by synthetic materials" by. Gondwana Res. 2020, 79, 301-303. [CrossRef]

151. Galaz, E.G.; Keppie, J.D.; Lee, J.K.W.; Ortega-Rivera, A. A high-pressure folded klippe at Tehuitzingo on the western margin of an extrusion zone, Acatlán Complex, southern México. Gondwana Res. 2013, 23, 641-660. [CrossRef] 
152. Mancera, G.G.; Gutiérrez, F.O.; Proenza, J.A.; Atudorei, V. Petrology and geochemistry of Tehuitzingo serpentinites (Acatlán Complex, SW Mexico). Bol. Soc. Geol. Mex. 2009, 61, 419-435. [CrossRef]

153. Ortega-Gutiérrez, F.; Elías-Herrera, M.; Morán-Zenteno, D.J.; Solari, L.; Weber, B.; Luna-González, L. The pre-Mesozoic metamorphic basement of Mexico, 1.5 billion years of crustal evolution. Earth-Sci. Rev. 2018, 183, 2-37. [CrossRef]

154. Shen, T.; Hermann, J.; Zhang, L.; Lü, Z.; Padrón-Navarta, J.A.; Xia, B.; Bader, T. UHP Metamorphism Documented in Tichondrodite- and Ti-clinohumite-bearing Serpentinized Ultramafic Rocks from Chinese Southwestern Tianshan. J. Petrol. 2015, 56, 1425-1458. [CrossRef]

155. Proenza, J.A.; Ortega-Gutiérrez, F.; Camprubí, A.; Tritlla, J.; Elías-Herrera, M.; Reyes-Salas, M. Paleozoic serpentinite-enclosed chromitites from Tehuitzingo (Acatlán Complex, southern Mexico): A petrological and mineralogical study. J. S. Am. Earth Sci. 2004, 16, 649-666. [CrossRef]

156. Kusky, T.; Wang, L.; Robinson, P.T.; Huang, Y.; Wirth, R.; Ning, W.; Zhong, Y.; Polat, A. Ultra-high pressure inclusion in Archean ophiolitic podiform chromitite in mélange block suggests deep subduction on early Earth. Precambrian Res. 2021, 362, 106318. [CrossRef] 